\title{
The Type III Secretion Chaperone HpaB Controls the Translocation of Effector and Noneffector Proteins From Xanthomonas campestris pv. vesicatoria
}

\author{
Felix Scheibner, Nadine Hartmann, Jens Hausner, Christian Lorenz, Anne-Katrin Hoffmeister, and \\ Daniela Büttner ${ }^{\dagger}$
}

Institute of Biology, Department of Genetics, Martin Luther University Halle-Wittenberg, D-06099 Halle (Saale), Germany

Accepted 2 August 2017.

\begin{abstract}
Pathogenicity of the gram-negative bacterium Xanthomonas campestris pv. vesicatoria depends on a type III secretion (T3S) system, which translocates effector proteins into plant cells. Effector proteins contain $\mathrm{N}$-terminal T3S and translocation signals and interact with the T3S chaperone $\mathrm{HpaB}$, which presumably escorts effectors to the secretion apparatus. The molecular mechanisms underlying the recognition of effectors by the T3S system are not yet understood. In the present study, we analyzed T3S and translocation signals in the type III effectors XopE2 and XopJ from X. campestris pv. vesicatoria. Both effectors contain minimal translocation signals, which are only recognized in the absence of HpaB. Additional $\mathrm{N}$-terminal signals promote translocation of XopE2 and XopJ in the wild-type strain. The results of translocation and interaction studies revealed that the interaction of XopE2 and XopJ with HpaB and a predicted cytoplasmic substrate docking site of the T3S system is not sufficient for translocation. In agreement with this finding, we show that the presence of an artificial HpaBbinding site does not promote translocation of the noneffector XopA in the wild-type strain. Our data, therefore, suggest that the T3S chaperone HpaB not only acts as an escort protein but also controls the recognition of translocation signals.
\end{abstract}

Pathogenicity of many gram-negative bacteria depends on the translocation of bacterial effector proteins into eukaryotic cells. Effector proteins interfere with various host cellular processes, such as signaling cascades, gene expression, and defense responses, and promote pathogen survival and multiplication (Büttner 2016; Dean 2011; Raymond et al. 2013). Effector protein delivery is often mediated by the translocation-associated type III secretion (T3S) system, which is conserved in different

Current address for Nadine Hartmann: La Jolla Institute for Allergy and Immunology, 9420 Athena Circle, La Jolla, CA, U.S.A.

Current address for Christian Lorenz: Department of Microbiology and Molecular Genetics, Harvard Medical School, Boston, MA, U.S.A.

Current address for Anne-Katrin Hoffmeister: Institute of Agricultural and Nutritional Sciences, Martin Luther University Halle-Wittenberg, D-06099 Halle (Saale), Germany.

${ }^{\dagger}$ Corresponding author: Daniela Büttner;

E-mail: daniela.buettner@genetik.uni-halle.de

*The $\boldsymbol{e}$-Xtra logo stands for "electronic extra" and indicates that seven supplementary figures and one supplementary table are published online.

(c) 2018 The American Phytopathological Society plant- and animal-pathogenic bacteria and is evolutionarily related to the bacterial flagellum (Diepold and Armitage 2015; He 1998). While the flagellar T3S system is linked to an extracellular filament, translocation-associated T3S systems are associated with a pilus (up to $2 \mu \mathrm{m}$ long; in plant-pathogenic bacteria) or needle (40 to $80 \mathrm{~nm}$ long, in animal-pathogenic bacteria). T3S pili or needles presumably serve as transport channels for secreted proteins to the host-pathogen interface (Büttner 2012). A channel-like bacterial T3S translocon in the eukaryotic plasma membrane mediates the subsequent translocation of effector proteins (Galán et al. 2014; Matteï et al. 2011; Mueller et al. 2008).

Despite the differences in the extracellular appendages of flagellar and translocation-associated T3S systems, at least eight components of the membrane-spanning secretion apparatus are conserved in different bacterial species. According to a universal nomenclature, conserved components of T3S systems were designated Sct (secretion and cellular translocation) proteins in animalpathogenic bacteria followed by a letter that refers to the Ysc proteins of the T3S system from Yersinia species (Hueck 1998). Sct proteins build the core structural elements of the secretion apparatus, which consists of ring structures in the inner and outer bacterial membrane and a predicted periplasmic inner rod (Büttner 2012; Deng et al. 2017). The inner membrane ring is associated with the export apparatus, which is assembled by members of five families of transmembrane proteins ( $\mathrm{SctU}, \mathrm{V}, \mathrm{R}, \mathrm{S}$, and $\mathrm{T})$ and presumably forms a transport channel for T3S substrates (Büttner 2012; Deng et al. 2017). Cytoplasmic components of the T3S system include the ATPase, which presumably provides the energy for, one or both, secretion or unfolding of T3S substrates, and the predicted cytoplasmic (C) ring, which is assembled by SctQ family members (Büttner 2012; Diepold et al. 2015; Hu et al. 2015, 2017).

One model organism for the analysis of T3S systems in plantpathogenic bacteria is the tomato and pepper pathogen Xanthomonas campestris pv. vesicatoria, which is the causal agent of bacterial spot disease. The T3S system from $X$. campestris pv. vesicatoria is encoded by the chromosomal hrp (hypersensitive response and pathogenicity) gene cluster, which is activated in planta or when the bacteria are cultivated in specific minimal media (Bonas et al. 1991; Wengelnik and Bonas 1996; Wengelnik et al. 1996). Among the T3S substrates from $X$. campestris pv. vesicatoria are effector, translocon, and pilus proteins as well as the predicted inner rod protein HrpB2 (Büttner and Bonas 2010; Rossier et al. 2000; Weber et al. 2005). Given that the predicted inner rod and the pilus are essential for T3S, a hierarchy in the secretion of different T3S substrates has been proposed. Thus, the T3S substrate specificity likely switches from the early substrate HrpB2 to middle and late substrates including translocon and effector proteins. This predicted hierarchy in T3S 
is presumably established by the cytoplasmic T3S substrate specificity switch (T3S4) protein $\mathrm{HpaC}$, which suppresses the secretion of HrpB2 and promotes the secretion of translocon and effector proteins (Büttner et al. 2006; Lorenz et al. 2008b).

Translocation of translocon and effector proteins is controlled by the T3S chaperone $\mathrm{HpaB}$ and its secreted regulator HpaA. HpaB promotes the translocation of effectors, presumably after the assembly of the translocon (Büttner et al. 2004). Previous interaction studies suggested that $\mathrm{HpaB}$ interacts with effector proteins and targets them to the ATPase of the T3S system (Büttner et al. 2004; Lorenz and Büttner 2009). The absence of $\mathrm{HpaB}$ interferes with effector protein translocation but promotes the translocation of translocon proteins (Büttner et al. 2004). Proteins such as components of the translocon that are only translocated in the absence of $\mathrm{HpaB}$ will hereafter be referred to as noneffectors. Experimental evidence suggests that the activity of $\mathrm{HpaB}$ is suppressed during the assembly of the T3S system, by the control protein HpaA (Lorenz et al. 2008a). Secretion and translocation of $\mathrm{HpaA}$ likely liberates $\mathrm{HpaB}$ and, thus, activates HpaB-dependent effector protein secretion after the T3S substrate specificity switch (Lorenz et al. 2008a). The mechanisms underlying the control of effector and noneffector translocation by $\mathrm{HpaB}$, however, are still unknown.

Secretion and translocation of T3S substrates depends on export signals, which are often present in the N-terminal 50 to 100 amino acids and are not conserved on the amino acid level (Arnold et al. 2009; Rüssmann et al. 2002; Schechter et al. 2004; Schesser et al. 1996; Sory et al. 1995). Sequence analyses revealed that the $\mathrm{N}$-terminal regions of T3S substrates are often unstructured and contain specific amino acid compositions or patterns (Arnold et al. 2009; Buchko et al. 2010; Löwer and Schneider 2009; McDermott et al. 2011; Samudrala et al. 2009; Schechter et al. 2004). However, export signals are not exclusively located in N-terminal regions of T3S substrates but have also been identified in C-terminal protein regions or in 5 '-untranslated regions of corresponding mRNAs (Allen-Vercoe et al. 2005; Anderson and Schneewind 1997, 1999; Chiu et al. 2003; Kim et al. 2007; Majander et al. 2005; Morello and Collmer 2009; Niemann et al. 2013; Tomalka et al. 2012). mRNA-based secretion signals are controversially discussed because a cotranslational secretion presumably does not account for the fast rate of effector protein translocation (Enninga et al. 2005; Mills et al. 2008; Schlumberger et al. 2005; VanEngelenburg and Palmer 2008; Winnen et al. 2008). It was, therefore, proposed that secretion of T3S substrates is mediated by composite signals in the mRNA and the $\mathrm{N}$ - or $\mathrm{C}$-terminal protein regions (Niemann et al. 2013; Schechter et al. 2012; Singer et al. 2014).

The mechanisms underlying the recognition of T3S signals by the secretion apparatus are not yet understood. Putative substrate docking sites include the predicted $\mathrm{C}$ ring of the T3S system, the cytoplasmic domains of SctU and SctV family members, and the cytoplasmic T3S ATPase, which was shown to interact with chaperone-substrate complexes (Akeda and Galán 2005; Büttner 2012; Deng et al. 2017; Lorenz and Büttner 2009; Thomas et al. 2005). Experimental evidence suggests that the T3S-ATPase dissociates chaperone-effector complexes and is involved in the unfolding of T3S substrates, which is a prerequisite for the passage of proteins across the inner secretion channel (Akeda and Galán 2005; Blocker et al. 2001; Galán et al. 2014; Lorenz and Büttner 2009). To date, experimental evidence for the recognition of export signal by components of the T3S system has been reported for the predicted inner rod protein HrpB2 from $X$. campestris pv. vesicatoria and the effector YopR from Yersinia enterocolitica (Scheibner et al. 2016; Sorg et al. 2006). In plant-pathogenic bacteria, however, export signals and their possible interactions with components of the T3S system have not yet been intensively studied.
In the present study, we aimed at the localization and characterization of export signals in the effector proteins XopE2 and XopJ from $X$. campestris pv. vesicatoria. We identified separate $\mathrm{N}$-terminal T3S and translocation signals as well as minimal translocation signals, which are suppressed in the wild-type strain by the T3S chaperone $\mathrm{HpaB}$. In vivo translocation and in vitro interaction studies showed that N-terminal deletion derivatives of XopE2 and XopJ interact with HpaB and the putative T3S substrate docking protein HrcQ but are not translocated by the wild-type strain. Our data, therefore, suggest that the interaction of effectors with $\mathrm{HpaB}$ and the T3S system is not sufficient for translocation.

\section{RESULTS}

\section{Localization of secretion signals} in the effector proteins XopE2 and XopJ.

To localize T3S signals in the type III effector XopE2, C-terminally c-Myc epitope-tagged derivatives of XopE2 and derivatives thereof deleted in amino acids 2 to 5,9 to 13 , or 2 to 10 were analyzed for in vitro T3S in $X$. campestris pv. vesicatoria $85-10 \mathrm{hrp} G^{*}\left(85^{*}\right)$. Strain $85^{*}$ is a derivative of the wild-type strain 85-10 and contains $\mathrm{HrpG}^{*}$, which is an active version of the key regulator HrpG and allows the constitutive expression of hrp genes (Wengelnik et al. 1999). When bacteria were incubated in secretion medium, XopE2-c-Myc and XopE2 $2_{\Delta 2-5}-\mathrm{c}-\mathrm{Myc}$ were detected in the culture supernatant, suggesting that they were secreted (Noël et al. 2002; Thieme et al. 2007) (Fig. 1A). In contrast, secretion of XopE2-c-Myc derivatives deleted in amino acids 9 to 13 or 2 to 10 was significantly reduced or not detectable (Fig. 1A). Notably, however, stability or synthesis of XopE2 ${ }_{\Delta 9-13^{-}}$ c-Myc in the cell extracts was also reduced (Fig. 1A). All strains secreted the translocon protein $\mathrm{HrpF}$, suggesting that the ectopic expression of xopE2 derivatives did not interfere with T3S (Fig. 1A). The predicted inner membrane ring protein $\mathrm{HrcJ}$ was only detected in cell extracts but not in culture supernatants, indicating that no cell lysis occurred (Fig. 1A).

Comparative sequence analysis revealed that the $\mathrm{N}$-terminal region of XopE2 is homologous to $\mathrm{N}$-terminal regions of the effector proteins XopE1 and XopJ, which contain conserved $\mathrm{N}$-myristoylation signals for membrane targeting in the plant cell (Thieme et al. 2007) (Fig. 1B). To confirm the contribution of the $\mathrm{N}$-terminal 10 amino acids to secretion, we analyzed derivatives of XopJ-c-Myc deleted in amino acids 2 to 5, 2 to 10, or 9 to 13. When compared with XopJ-c-Myc, secretion of $\mathrm{XopJ}_{\Delta 2-5}-\mathrm{c}-\mathrm{Myc}$

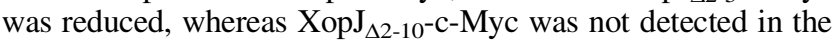
culture supernatant (Fig. 1C). This is in agreement with the results obtained for the corresponding XopE2 deletion derivatives (Fig. 1A). $\mathrm{XopJ}_{\Delta 9-13}-\mathrm{c}-\mathrm{Myc}$ was stably synthesized and secreted at wild-type levels (Fig. 1C). Taken together, these observations suggest that amino acids 6 to 8 are essential for secretion of XopE2 and XopJ.

\section{The N-terminal 20 amino acids of XopE2 are sufficient for secretion.}

To investigate whether the N-terminal regions of XopE2 and $\mathrm{XopJ}$ are sufficient for T3S and translocation, we generated fusion proteins between $\mathrm{N}$-terminal effector regions and the AvrBs3 $\Delta 2$ reporter protein. AvrBs $3 \Delta 2$ is an $\mathrm{N}$-terminal deletion derivative of the transcription activator-like (TAL) effector AvrBs3 from $X$. campestris pv. vesicatoria. TAL effectors bind, via specific amino acids in their central repeat region, to sequence motifs in the promoters of plant target genes and activate gene expression (Boch and Bonas 2010). AvrBs3 $\Delta 2$ lacks the N-terminal 152 amino acids and, thus, the T3S and translocation signal. However, AvrBs $3 \Delta 2$ contains the effector domain and, therefore, activates the expression of the resistance gene Bs3 in AvrBs3-responsive 
'Early Cal Wonder' (ECW)-30R pepper plants when delivered as fusion partner of a functional T3S and translocation signal (Boch et al. 2009; Noël et al. 2003; Szurek et al. 2002). Bs3 expression leads to the initiation of plant defense responses, which are associated with a hypersensitive response (HR), i.e., a local cell death at the infection site (Dangl and Jones 2001; Römer et al. 2007).

We first analyzed the in vitro T3S of AvrBs $3 \Delta 2$ fusion proteins containing the N-terminal 20,30,40,50, or 150 amino acids of
XopE2 or the full-length protein. All fusion proteins were secreted and detected in the culture supernatants of strain $85^{*}$ (Fig. 2A). Similar findings were observed for XopJ-AvrBs $3 \Delta 2$ fusion proteins containing the N-terminal 50 amino acids or the fulllength protein (Fig. 2B). It should be noted that all AvrBs $3 \Delta 2$ fusions were reproducibly secreted; however, the relative secretion levels varied in different experiments. Thus, the $\mathrm{N}$-terminal 20 and 50 amino acids of XopE2 and XopJ, respectively, are sufficient for secretion of the AvrBs $3 \Delta 2$ reporter.
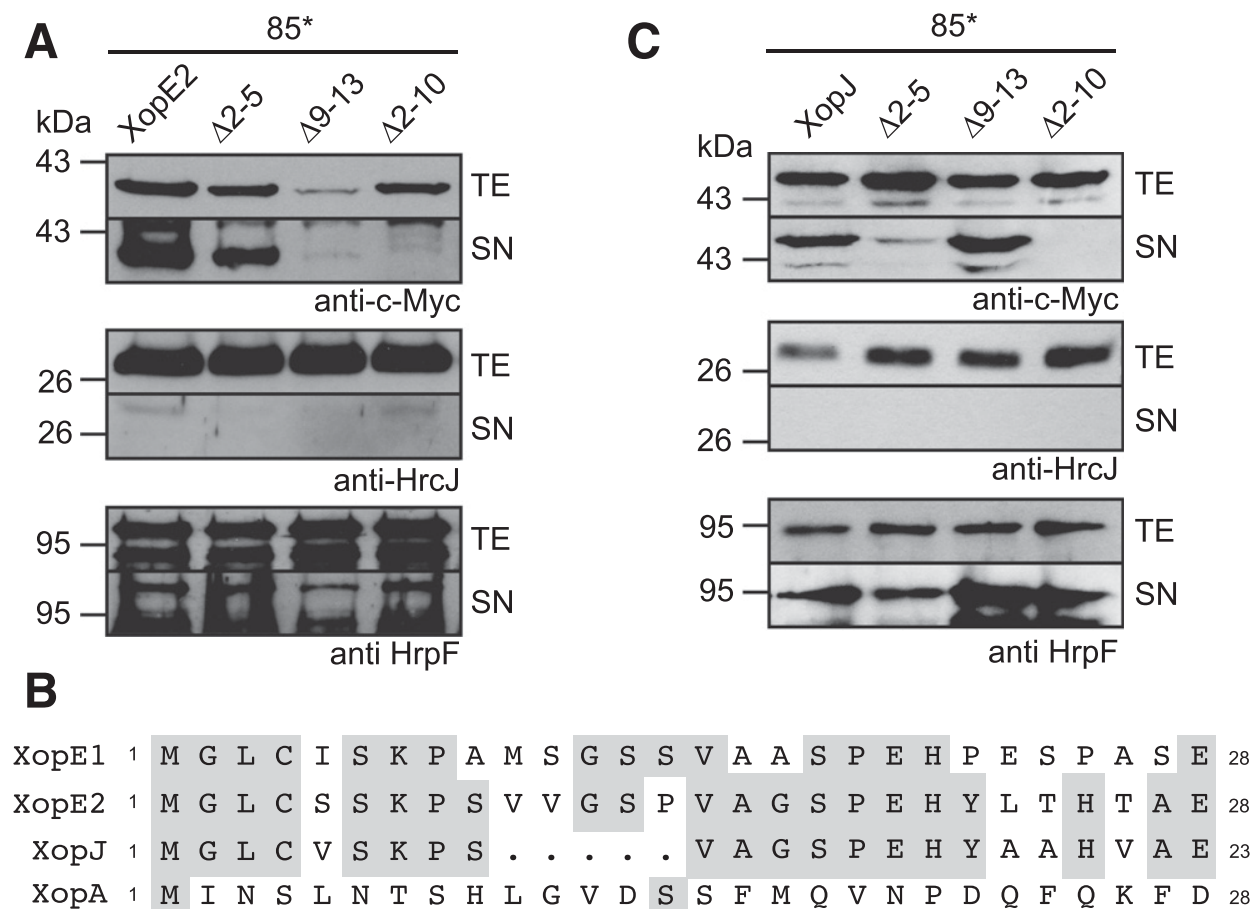

Fig. 1. Amino acids 6 to 8 of XopE2 and XopJ are essential for type III secretion (T3S). A, T3S assays with XopE2-c-Myc and derivatives thereof. Strain 85* containing XopE2-c-Myc or N-terminal deletion derivatives thereof lacking amino acids 2 to 5,9 to 13, or 2 to 10 was incubated in secretion medium. Total cell extracts (TE) and culture supernatants (SN) were analyzed by immunoblotting, using antibodies specific for the c-Myc epitope, the inner membrane ring protein HrcJ, and the translocon protein HrpF. B, The N-terminal regions of XopE1, XopE2 and XopJ share amino acid identities. The N-terminal amino acid sequences of XopE1, XopE2, XopJ, and XopA are shown. Numbers refer to amino acid positions. Gray boxes indicate identical amino acids. C, Deletion of

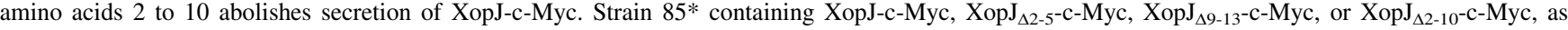
indicated, was incubated in secretion medium. TE and SN were analyzed as described in A.
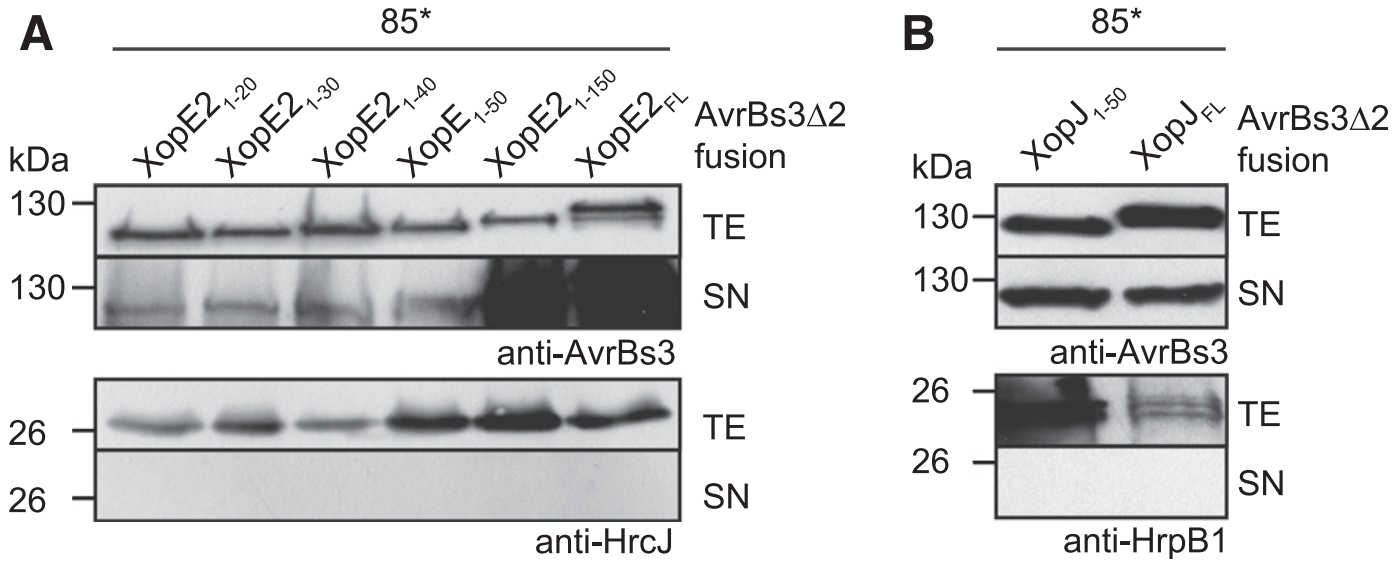

Fig. 2. The N-terminal 20 amino acids of XopE2 are sufficient for type III secretion. A, In vitro secretion of XopE2-AvrBs3 $\Delta 2$ fusion proteins. Strain $85^{*}$ encoding XopE2 $2_{1-20^{-}}$, XopE2 $2_{1-30^{-}}, \mathrm{XopE}_{1-40^{-}}, \mathrm{XopE} 2_{1-50^{-}}, \mathrm{XopE} 2_{1-150^{-}}$, or XopE2 $2_{\mathrm{FL}}-\mathrm{AvrBs} 3 \Delta 2$ fusion proteins, as indicated, was incubated in secretion medium. Total cell extracts (TE) and culture supernatants (SN) were analyzed by immunoblotting, using antibodies specific for AvrBs3 and the inner membrane ring protein HrcJ. B,

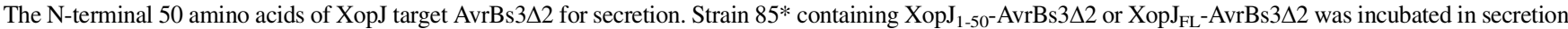
medium. TE and SN were analyzed by immunoblotting, using antibodies specific for AvrBs3 and the periplasmic protein HrpB1. 


\section{XopE2 and XopJ contain separate T3S and translocation signals.}

For in vivo translocation assays, strain $85^{*}$ containing AvrBs $3 \Delta 2$ reporter fusions was infiltrated into leaves of AvrBs3-responsive pepper plants. XopE2 $2_{\mathrm{FL}}-\mathrm{AvrBs} 3 \Delta 2$ and $\mathrm{XopE} 2_{1-150}$-AvrBs $3 \Delta 2$ induced the AvrBs3-specific HR, suggesting that they were translocated (Fig. 3A). In contrast, AvrBs $3 \Delta 2$ fusion proteins containing the N-terminal 20,30,40, or 50 amino acids of XopE2 did not induce the HR when delivered by strain $85^{*}$ (Fig. 3A). As a control, bacteria were infiltrated into leaves of AvrBs1-responsive pepper plants. All strains induced the AvrBs1-specific HR, suggesting that the ectopic expression of $a v r B s 3 \Delta 2$ fusions did not interfere with the delivery of AvrBs1 and, thus, with the activity of the T3S system (Supplementary Fig. S1). Given that all fusions were secreted (discussed above) (Fig. 2A), we assume that XopE2 contains separate secretion and translocation signals within the $\mathrm{N}$-terminal 20 and 150 amino acids. Similarly, the N-terminal 50 amino acids of XopJ, which are sufficient for T3S, did not target the AvrBs3 32 reporter for translocation, suggesting that the T3S signal is not sufficient for translocation (Fig. 4A).

XopE2 and XopJ contain minimal translocation signals.

We also analyzed the translocation of AvrBs $3 \Delta 2$ fusion proteins in strain $85^{*} \Delta h p a B$, which lacks the T3S chaperone HpaB. Compared with the wild-type strain $85^{*}$, XopE2 ${ }_{1-150}$-AvrBs $3 \Delta 2$ induced a significantly reduced $\mathrm{HR}$ when delivered by strain $85^{*} \Delta h p a B$ (Fig. 3A). In contrast, XopE2 $2_{\mathrm{FL}}-\mathrm{AvrBs} 3 \Delta 2$ was efficiently translocated in the absence of HpaB (Fig. 3A). In the $h r p G$ wild-type strain 85-10 $\triangle h p a B$, however, the translocation of both fusions was only detectable when bacteria were infiltrated at high densities (Supplementary Fig. S2). This suggests that the overexpression of $h r p$ genes in strain $85^{*}$ can at least partially compensate for the absence of $\mathrm{HpaB}$.

Notably, XopE2 $2_{1-40^{-}}$AvrBs3 $3 \Delta 2$ induced a weak HR when delivered by strain $85^{*} \Delta h p a B$ (Fig. 3A). This implies that the $\mathrm{N}$-terminal 40 amino acids of XopE2 contain a translocation signal that is functional in the absence of HpaB. Translocation signals, which are recognized in $h p a B$ deletion mutants but not in the wildtype strain, will hereafter be referred to as minimal translocation signals. Translocation of XopE2 ${ }_{1-40}-\mathrm{AvrBs} 3 \Delta 2$ in the $h p a B$ deletion mutant was type III-dependent because the translocondeficient strain $85^{*} \Delta h p a B \Delta h r p F$ containing XopE2 $2_{1-40}$-AvrBs $3 \Delta 2$ failed to induce the HR (Fig. 3B). No HR was observed after inoculation with strain $85^{*}$ containing XopE2 ${ }_{1-50}$-AvrBs $3 \Delta 2$ (Fig. 3A). This was presumably not caused by a misfolding of the AvrBs3 32 reporter because XopE2 ${ }_{1-50}$-AvrBs $3 \Delta 2$ induced the AvrBs3-specific HR when transiently expressed under control of the $35 \mathrm{~S}$ promoter in AvrBs3-responsive ECW-30R pepper leaves (Fig. 3C). It cannot be excluded that the recognition of the minimal translocation signal in the N-terminal 40 amino acids of XopE2 depends on a certain protein conformation that is altered in the context of larger protein regions.

In addition to XopE2, we also identified a minimal translocation

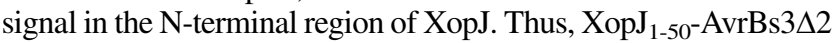
was translocated by strains $85^{*} \Delta h p a B$ and $85-10 \Delta h p a B$ but not by strain $85^{*}$ or the translocation-deficient strain $85^{*} \Delta h p a B \Delta h r p F$

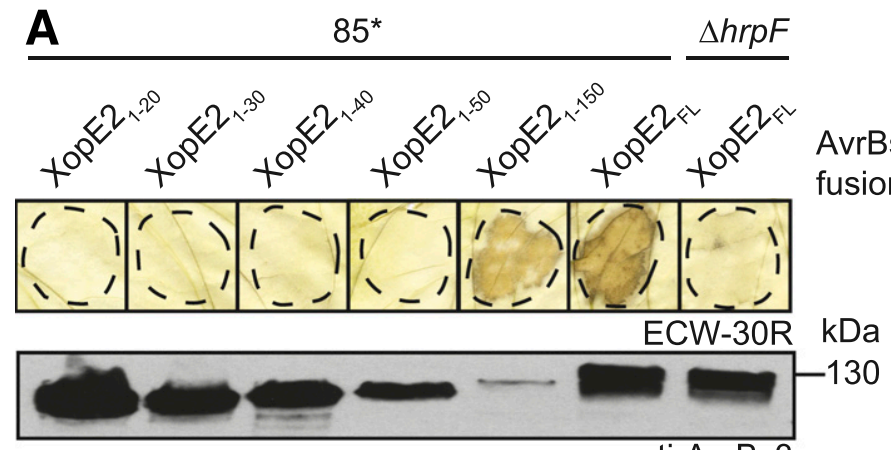

anti-AvrBs3

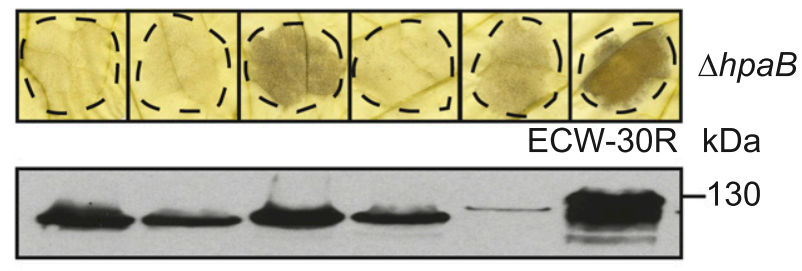

anti-AvrBs3
B
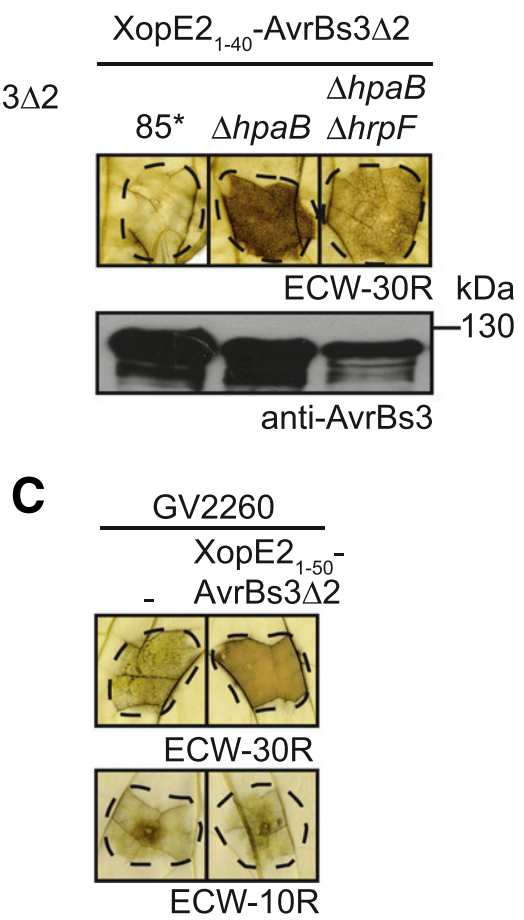

Fig. 3. Localization of translocation signals in XopE2. A, In vivo translocation assays with $\mathrm{XopE} 22_{1-\mathrm{X}}-\mathrm{AvrBs} 3 \Delta 2$ fusion proteins. Strains $85^{*}, 85^{*} \Delta h r p F$ $(\triangle h r p F)$, and $85^{*} \Delta h p a B(\triangle h p a B)$ containing XopE2 ${ }_{1-\mathrm{X}}$-AvrBs3 32 fusion proteins were infiltrated into leaves of AvrBs3-responsive ECW-30R pepper plants. Dashed lines indicate the infiltrated areas. Leaves were destained 3 days postinoculation (dpi). Equal amounts of cell extracts were analyzed by immunoblotting, using an AvrBs3-specific antiserum. Note that reduced amounts of XopE2 $1-150^{-A v r B s} 3 \Delta 2$ were detected in the total cell extracts when compared with other

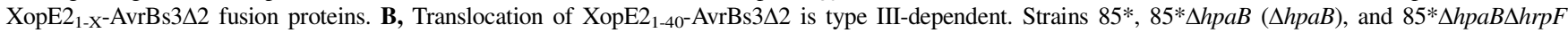
$(\triangle h p a B \Delta h r p F)$ encoding XopE2 $1-40^{-A v r B s} 3 \Delta 2$ were infiltrated into leaves of AvrBs3-responsive pepper plants. Leaves were destained 3 dpi. Plant reactions and cell extracts were analyzed as described in A. C, Transient expression of $x o p E 2_{1-50^{-}}$avrBs $3 \Delta 2$ in AvrBs3-responsive pepper plants induces the hypersensitive response. Agrobacterium tumefaciens GV2260 without expression construct (-) or containing a binary vector encoding XopE2 $2_{1-50}$ AvrBs $3 \Delta 2$ under control of the $35 S$ promoter was infiltrated, at a density of $8 \times 10^{8} \mathrm{CFU} \mathrm{ml}{ }^{-1}$, into leaves of AvrBs3-responsive ECW-30R and AvrBs1-responsive ECW-10R plants. Leaves of ECW-30R plants were destained in ethanol 3 dpi, leaves of ECW-10R plants 2 dpi. 
(Fig. 4A and B; Supplementary Fig. S3). In contrast, $\mathrm{XopJ}_{\mathrm{FL}^{-}}$ AvrBs $3 \Delta 2$ did not induce the HR when delivered by strain $85^{*} \Delta h p a B$, suggesting that the translocation of the full-length XopJ protein depends on HpaB (Fig. 4A).

\section{The N-terminal regions of XopE2 and XopJ are dispensable for translocation in $h p a B$ deletion mutants.}

To analyze the contribution of the minimal translocation signals to the delivery of XopE2 and XopJ, we generated XopE2and $\mathrm{XopJ}-\mathrm{AvrBs} 3 \Delta 2$ fusion proteins lacking amino acids 2 to 40 and 2 to 50, respectively. Unexpectedly, XopE2 $2_{\Delta 2-40^{-A v r B s} 3 \Delta 2}$ induced the AvrBs3-specific HR when delivered by strain $85^{*} \Delta h p a B$ but not by strain $85^{*}$ (Fig. 4C). A partial HR induction was observed with strain $85-10 \triangle h p a B$ whereas strain $85^{*}$ or the translocationdeficient strain $85^{*} \Delta h p a B \Delta h r p F$ containing XopE2 ${ }_{\Delta 2-40}$-AvrBs $3 \Delta 2$ failed to induce the HR (Fig. $4 \mathrm{C}$ and D). Similarly, $\mathrm{XopJ}_{\triangle 2-50^{-}}$ AvrBs $3 \Delta 2$ was translocated by strains $85^{*} \Delta h p a B$ and $85-10 \Delta h p a B$ but not by strains $85^{*}, 85-10$ and $85^{*} \Delta h p a B \Delta h r p F$ (Fig. 4A and B). $\mathrm{We}$, therefore, assume that the absence of $\mathrm{HpaB}$ allows the recognition of alternative $\mathrm{T} 3 \mathrm{~S}$ and translocation signals, which are located outside the N-terminal regions of XopE2 and XopJ. The finding that $\mathrm{N}$-terminal deletion derivatives of XopE2 and XopJ are translocated by $h p a B$ deletion mutants also indicates that the N-terminal T3S signals of XopE2 and XopJ are dispensable for protein translocation in the absence of $\mathrm{HpaB}$.

\section{N-terminal deletion derivatives of XopE2 and XopJ interact with the T3S chaperone $\mathrm{HpaB}$ and the predicted $\mathrm{C}$ ring protein HrcQ.}

The mechanisms underlying the recognition of $\mathrm{T} 3 \mathrm{~S}$ and translocation signals are still largely unknown. Putative substrate docking sites include the ATPase $\mathrm{HrcN}$, which interacts with HpaB-effector complexes, and the putative $\mathrm{C}$ ring protein HrcQ (Lorenz and Büttner 2009; Lorenz et al. 2012). To analyze a potential contribution of the N-terminal regions of XopE2 and XopJ to the interaction with HrcQ or HpaB, we performed in vitro glutathione- $S$-transferase (GST) pull-down assays. For this, GST, GST-XopE2, and GST-XopJ, as well as GST fusions of N-terminal deletion derivatives of XopE2 and XopJ were immobilized on glutathione sepharose and were incubated with bacterial lysates containing HrcQ-c-Myc or HpaB-c-Myc. HrcQ-c-Myc coeluted with all tested GST fusion proteins but was not or only weakly detectable in the eluate of GST (Fig. 5A and B). Similarly, HpaB-c-Myc coeluted with GST fusions of XopE2, XopE2 $2_{\Delta 2-40}$, XopJ, and $\mathrm{XopJ}_{\Delta 2-50}$ but not with GST alone (Fig. 5C and D). These findings suggest that the N-terminal regions of XopE2 and XopJ are dispensable for the interaction with one or both $\mathrm{HpaB}$ and HrcQ. The lack of secretion of N-terminal deletion derivatives of XopE2 and XopJ is, therefore, presumably not caused by a lack of interaction with the putative $\mathrm{C}$ ring or the T3S chaperone HpaB.
A

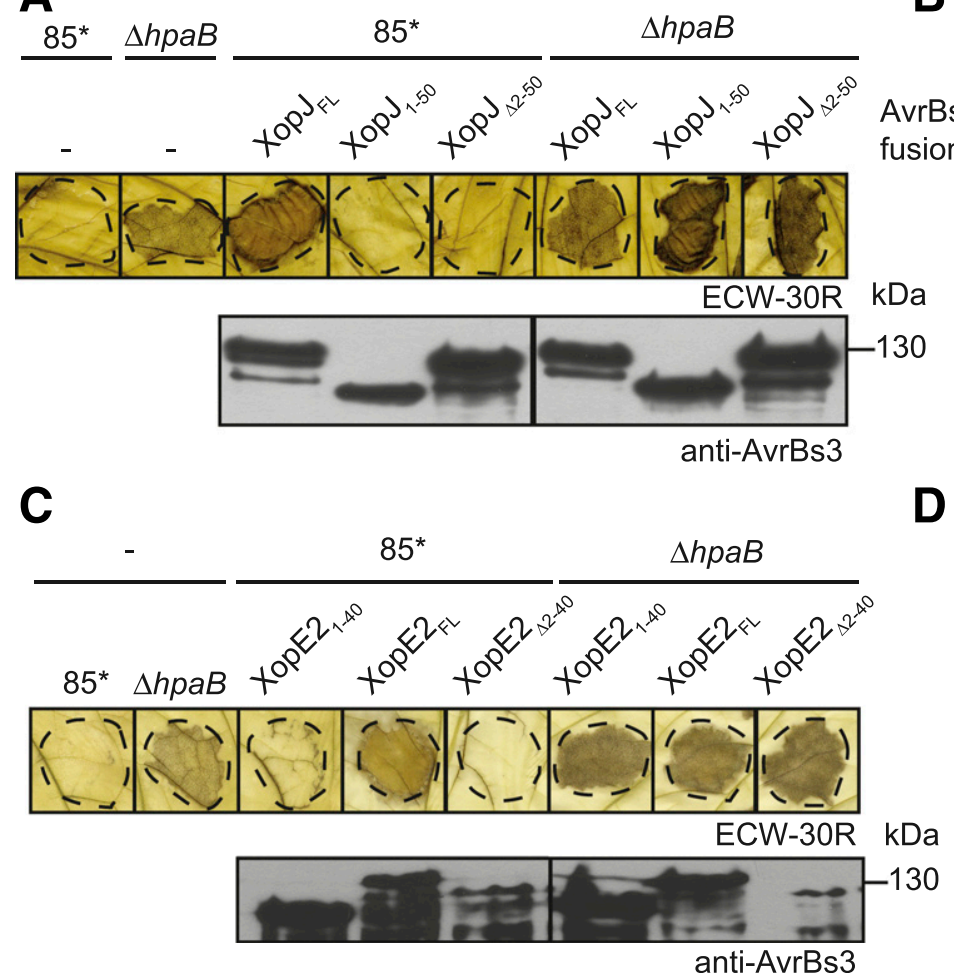

B

$\Delta h p a B$ 85* $\Delta h p a B \Delta h r p F$

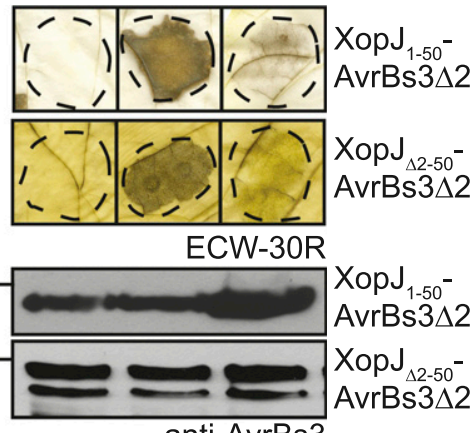

anti-AvrBs3

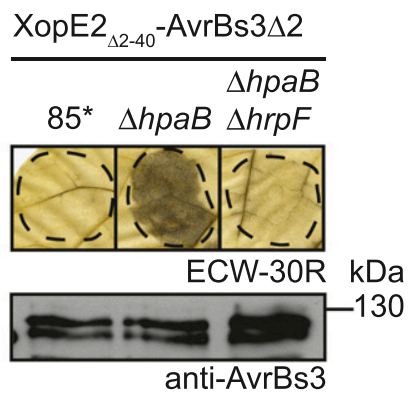

Fig. 4. Identification of minimal translocation signals in XopJ and XopE2. A, In vivo translocation assays with $\mathrm{XopJ}_{1-\mathrm{X}^{-}} \mathrm{AvrBs} 32$ fusion proteins. Strains $85^{*}$

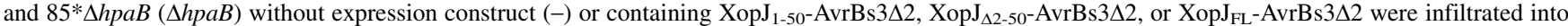
leaves of AvrBs3-responsive ECW-30R pepper plants. Dashed lines indicate the infiltrated areas. Leaves were destained 3 days postinoculation (dpi). The brown color of the leaf area infected with strain $85^{*} \Delta h p a B$ containing $\mathrm{XopJ}_{\mathrm{FL}}-\mathrm{AvrBs} 32$ is a background reaction that was also observed after infection with strain $85^{*} \Delta h p a B$ without expression construct. Equal amounts of cell extracts were analyzed by immunoblotting, using an AvrBs3-specific antiserum. B, Translocation of $\mathrm{XopJ}_{1-50}-\operatorname{AvrBs} 3 \Delta 2$ and $\mathrm{XopJ}_{\Delta 2-50}-\mathrm{AvrBs}_{\Delta} \Delta 2$ depends on the type III secretion (T3S) system. Strains $85^{*}, 85^{*} \Delta h p a B(\Delta h p a B)$ and $85^{*} \Delta h p a B \Delta h r p F(\Delta h p a B \Delta h r p F)$ encoding $\mathrm{XopJ}_{1-50}-\mathrm{AvrBs} \Delta 2$ or $\mathrm{XopJ}_{\Delta 2-50}-\mathrm{AvrBs} \Delta 2$ were infiltrated into leaves of AvrBs3-responsive pepper plants, and leaves were destained $3 \mathrm{dpi}$. Strains containing $\mathrm{XopJ}_{\Delta 2-50^{-}}$AvrBs $3 \Delta 2$ were infiltrated at an optical density of $8 \times 10^{8} \mathrm{CFU} \mathrm{ml}^{-1}$. Plant reactions and cell extracts were analyzed as described in A. C, Deletion of amino acids 2 to 40 does not abolish translocation of XopE2. Strains $85^{*}$ and $85^{*} \Delta h p a B(\Delta h p a B)$ without expression construct (-) or encoding XopE2-AvrBs3 $\Delta 2$ fusion proteins were infiltrated into leaves of AvrBs3-responsive pepper plants. Plant reactions and cell extracts were analyzed as described in A. Plant reactions on ECW-10R plants are shown in Supplementary Figure S4. D, Translocation of XopE2 $2_{\Delta 2-40}$-AvrBs $3 \Delta 2$ depends on the T3S system. Strains $85^{*}, 85^{*} \Delta h p a B(\Delta h p a B)$, and $85^{*} \Delta h p a B \Delta h r p F(\Delta h p a B \Delta h r p F)$ encoding XopE2 $\Delta 2-40^{-A v r B s} 3 \Delta 2$ were infiltrated into leaves of AvrBs3-responsive pepper plants. Leaves were destained 3 dpi. Plant reactions and cell extracts were analyzed as described in A. 
The noneffector XopA contains separate T3S and minimal translocation signals.

In addition to the effector proteins XopE2 and XopJ, we analyzed export signals in the noneffector protein XopA, which is secreted by the T3S system and contributes to bacterial virulence (Noël et al. 2002). Previous translocation assays suggested that XopA is translocated in the absence of $\mathrm{HpaB}$ but not in the wild-type strain (Büttner et al. 2004). To localize the T3S and minimal translocation signal in XopA, we generated c-Myc epitope-tagged derivatives of XopA as well as XopA-AvrBs $3 \Delta 2$ fusion proteins. In vitro T3S assays showed that XopA-c-Myc was secreted by strain $85^{*}$, whereas secretion of an N-terminal deletion derivative lacking amino acids 2 to 5 was reduced (Fig. 6A). Deletion of amino acids 2 to 10 or 2 to 21 abolished the detectable secretion of XopA-c-Myc, which is in agreement with the results obtained for XopE2 and XopJ derivatives (Fig. 6A) (discussed above).

AvrBs3 $\Delta 2$ fusions containing the N-terminal 20, 25, or 30 amino acids of XopA were secreted by strains $85^{*}$ and $85^{*} \Delta h p a B$, suggesting that amino acids 6 to 20 contain the T3S signal of XopA (Fig. 6B). In vivo translocation assays showed that the N-terminal 30 amino acids of XopA target the AvrBs $3 \Delta 2$ reporter for translocation in strain $85^{*} \Delta h p a B$ but not in the wild-type strain or the translocation-deficient strain $85^{*} \Delta h p a B \Delta h r p F$ (Fig. 6C; Supplementary Fig. S5). In contrast, the N-terminal 20 amino acids of XopA were not sufficient for translocation, suggesting that XopA contains separate T3S and translocation signals (Fig. 6C). Deletion of amino acids 2 to 10 but not of amino acids 2 to 5 abolished the translocation of XopA-AvrBs3 $\Delta 2$ (Fig. 6D). This is in agreement with the finding that amino acids 2 to 5 are dispensable for secretion of XopA (Fig. 6A).

\section{The presence of an artificial HpaB-binding site does not promote the translocation of the noneffector XopA in the wild-type strain.}

In contrast to effector proteins, XopA does not interact with the T3S chaperone $\mathrm{HpaB}$ and is only translocated in the absence of HpaB (Büttner et al. 2004). To investigate whether the
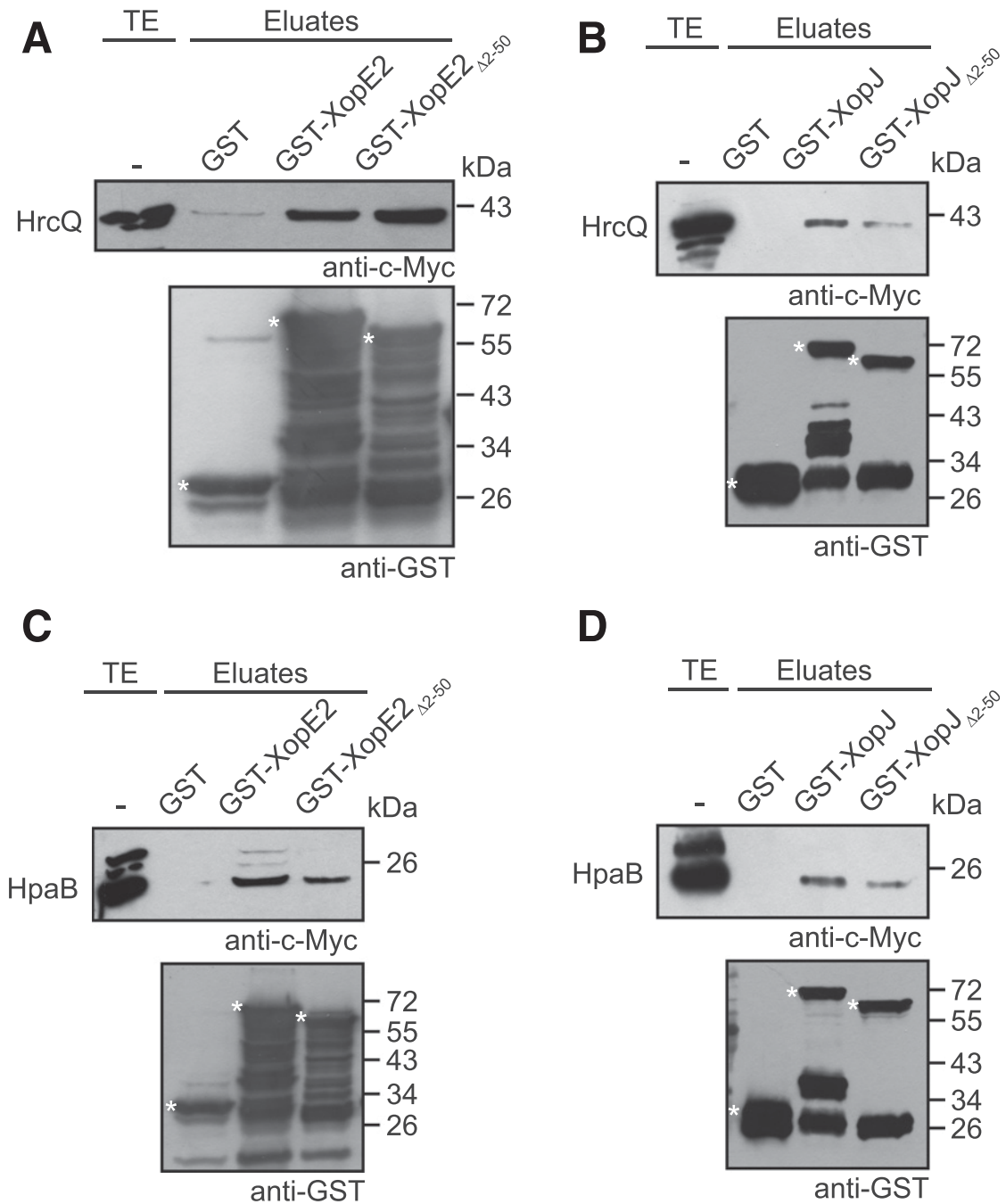

Fig. 5. N-terminal deletion derivatives of XopE2 and XopJ interact with the predicted C ring protein HrcQ and the type III secretion chaperone HpaB. A, Nterminal deletion derivatives of XopE2 interact with HrcQ. Glutathione-S-transferase (GST), GST-XopE2 and GST-XopE2 ${ }_{\Delta 2-40}$ were immobilized on glutathione sepharose and were incubated with a bacterial lysate containing HrcQ-c-Myc. The total cell extract (TE) containing HrcQ-c-Myc and eluted proteins (eluates) were analyzed by immunoblotting, using antibodies against the c-Myc epitope or GST. GST and GST fusion proteins are marked with asterisks, lower bands represent degradation products. B, The N-terminal 50 amino acids of XopJ are dispensable for the interaction with HrcQ. Immobilized GST and GST fusion proteins were incubated with a bacterial lysate containing HrcQ-c-Myc. TE and eluates were analyzed as described in A. C, An Nterminal deletion derivative of XopE2 interacts with HpaB. Immobilized GST and GST fusion proteins were incubated with a bacterial lysate containing HpaBc-Myc. TE and eluates were analyzed as described in A. D, The N-terminal 50 amino acids of XopJ are dispensable for the interaction with HpaB. Immobilized GST and GST fusion proteins were incubated with a bacterial lysate containing HpaB-c-Myc. TE and eluates were analyzed as described in A. 
presence of an artificial HpaB-binding site would promote translocation of XopA in the wild-type strain, we generated a fusion protein between XopA and the HpaB-binding site of $\mathrm{HpaA}$, which is the secreted regulator of $\mathrm{HpaB}$. The HpaBbinding site was previously localized to the $\mathrm{C}$-terminal 50 amino acids of HpaA (Lorenz et al. 2008a). The interaction of $\mathrm{HpaB}$ with the fusion protein consisting of XopA and the $\mathrm{C}$-terminal 50 amino acids of $\mathrm{HpaA}$ was confirmed by in vitro GST pull-down assays. Figure 7A shows that HpaB-c-Myc coeluted with GST-XopA-HpaA $\mathrm{C}_{50}$ but not with GST or GSTXopA. Similarly, a C-terminally c-Myc epitope-tagged derivative of XopA-HpaA ${ }_{\mathrm{C} 50}$ coeluted with GST-HpaB but not with GST (Fig. 7B). In vivo translocation assays revealed that a XopA-HpaA $\mathrm{C}_{50}$-AvrBs $3 \Delta 2$ reporter fusion induced the HR when delivered by strain $85^{*} \Delta h p a B$ but not by the wild-type strain or the translocation-deficient strain $85^{*} \Delta h p a B \Delta h r p F$ (Fig. 7C and D). The results of all in vitro secretion and in vivo translocation assays are summarized in Table 1. Taken together,
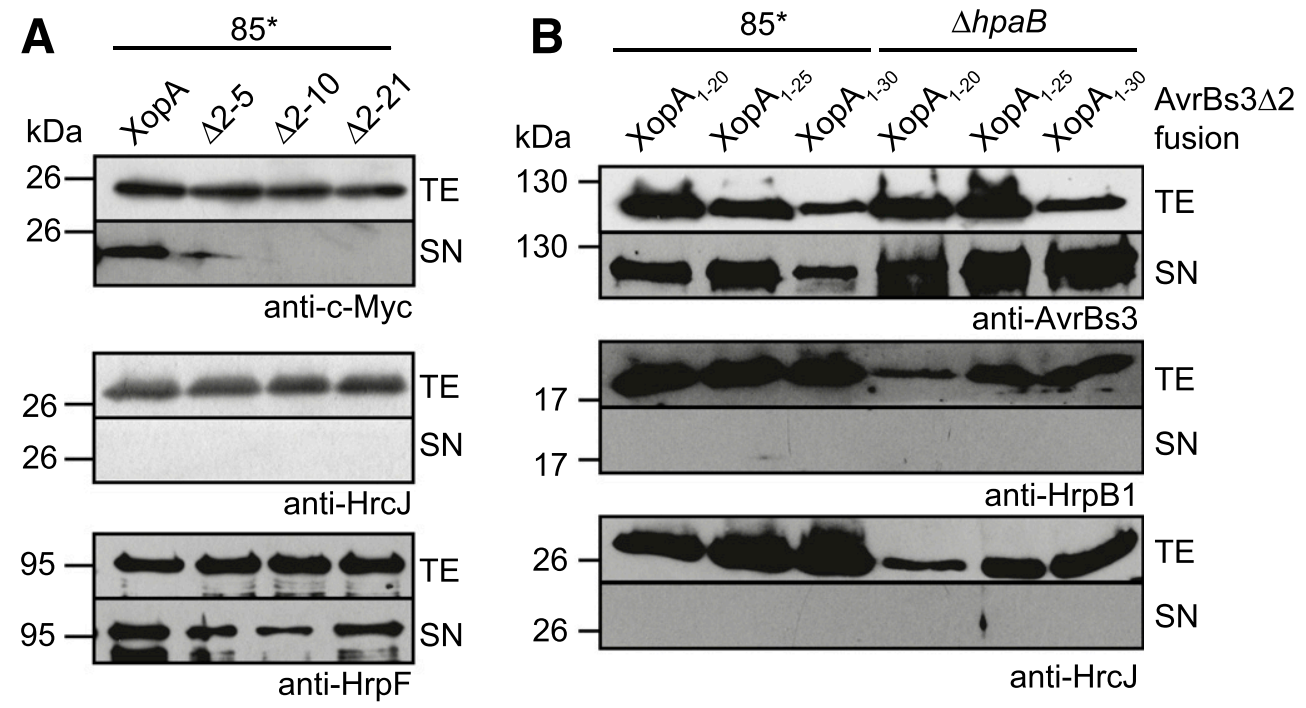

C

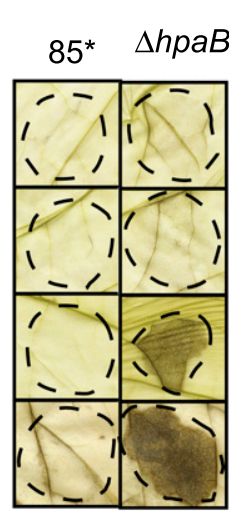

AvrBs $3 \Delta 2$ fusion XopA $1-20$

XopA 1-25 XopA 1-30

XopA 1-30(pnat)

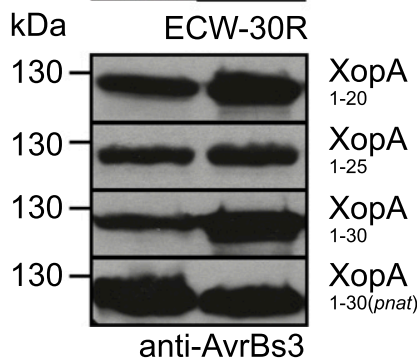

D $85^{\star} \quad \Delta h p a B$ fusion

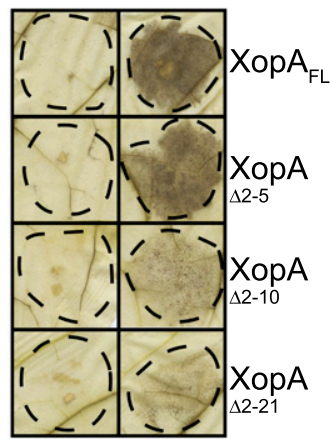

$\mathrm{kDa}$

ECW-30R

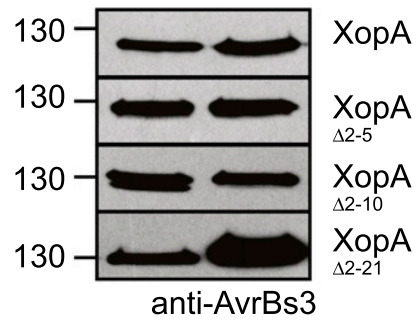

Fig. 6. XopA contains separate type III secretion (T3S) and minimal translocation signals. A, Amino acids 2 to 5 are dispensable for secretion of XopA. Strain $85^{*}$, containing XopA-c-Myc and N-terminal deletion derivatives thereof lacking amino acids 2 to 5,2 to 10 , or 2 to 21 , was incubated in secretion medium. Total cell extracts (TE) and culture supernatants (SN) were analyzed by immunoblotting, using antibodies specific for the c-Myc epitope, the inner membrane protein $\mathrm{HrcJ}$, or the secreted translocon protein $\mathrm{HrpF}$. B, Amino acids 1 to 20 of XopA target the AvrBs $3 \Delta 2$ reporter for T3S. Strains $85^{*}$ and $85^{*} \Delta h p a B$ containing $\mathrm{XopA}_{1-20}-\mathrm{AvrBs} 3 \Delta 2$, $\mathrm{XopA}_{1-25}-\mathrm{AvrBs} 3 \Delta 2$, or $\mathrm{XopA}_{1-30}-\mathrm{AvrBs} 3 \Delta 2$ were incubated in secretion medium. TE and $\mathrm{SN}$ were analyzed by immunoblotting, using antibodies specific for the c-Myc epitope, the periplasmic protein HrpB1, or the inner membrane protein HrcJ. C, Translocation of XopA

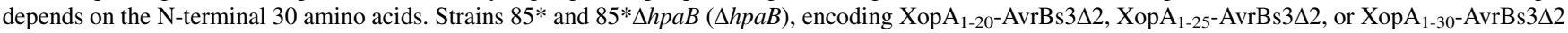
under control of the lac or the native promoter (pnat), were infiltrated into leaves of AvrBs3-responsive ECW-30R pepper plants. For better visualization of the hypersensitive response, leaves were destained in ethanol 3 days postinoculation. Dashed lines indicate the infiltrated areas. Equal amounts of cell extracts were analyzed by immunoblotting, using an AvrBs3-specific antiserum. D, Amino acids 2 to 5 are dispensable for the translocation of XopA. Strains 85* and $85^{*} \Delta h p a B(\Delta h p a B)$ encoding XopA-AvrBs3 32 fusion proteins were infiltrated into leaves of AvrBs3-responsive pepper plants. Plant reactions and cell extracts were analyzed as described in $\mathrm{C}$. 
our data suggest that the interaction of T3S substrates with HpaB is not sufficient for translocation.

\section{DISCUSSION}

In the present study, we provide experimental evidence that the effectors XopE2 and XopJ from X. campestris pv. vesicatoria contain composite export signals that control secretion and translocation in wild-type or $h p a B$ mutant strains. The results of in vitro T3S assays suggest that the T3S signals of XopE2 and XopJ are located in the N-terminal 20 amino acids with amino acids 2 to 5 being dispensable for T3S. In contrast, amino acids 6 to 8 of XopE2 and XopJ are essential for secretion (Fig. 1). This is in agreement with the previous finding that amino acids 6 to 10 of T3S signals presumably contain critical features for T3S (Wang et al. 2013). The translocation signals of XopE2 and XopJ were previously localized in the N-terminal 150 and 155 amino acids, respectively (Noël et al. 2003; Thieme et al. 2007). Here, we show that the N-terminal 50 amino acids of both proteins are not sufficient for translocation in the wild-type strain, suggesting that XopE2 and XopJ contain separate signals for T3S and translocation (Fig. 3 and 4). Similar findings were reported for the effector protein AvrBs2 from $X$. campestris pv. vesicatoria as well as for effector proteins from the plant-pathogenic bacterium Erwinia amylovora and the human pathogen Yersinia spp. (Mudgett et al. 2000; Oh et al. 2010; Schesser et al. 1996; Sory et al. 1995). The predicted inner rod protein HrpB2 from X. campestris pv. vesicatoria, however, presumably contains a joint secretion and translocation signal, suggesting that the organization of export signals can differ in early and late T3S substrates (Scheibner et al. 2016)

It was previously reported that the $\mathrm{N}$-terminal regions of the effector proteins XopE1, XopE2, and XopJ contain $\mathrm{N}$-myristoylation signals, which presumably target the proteins to the plant plasma membrane after translocation (Thieme et al. 2007). The N-myristoylation motifs are conserved in XopE1, XopE2 and XopJ; however, homologous amino acid sequences are absent in the $\mathrm{N}$-terminal regions of other T3S substrates. This is in agreement with the general assumption that T3S signals are not conserved on the amino acid level (Arnold et al. 2009; Buchko et al. 2010; Löwer and Schneider 2009; McDermott et al. 2011; Samudrala et al. 2009; Schechter et al. 2004). Export signals of T3S substrates from plant- and animalpathogenic bacteria were reported to contain characteristic amino acid compositions including a high content of polar (especially serine) residues (Greenberg and Vinatzer 2003; Guttman et al. 2002; Petnicki-Ocwieja et al. 2002; Schechter et al. 2004, 2006). Mutation of predicted characteristic N-terminal amino acids in the type III effector AvrPto from the plant-pathogenic
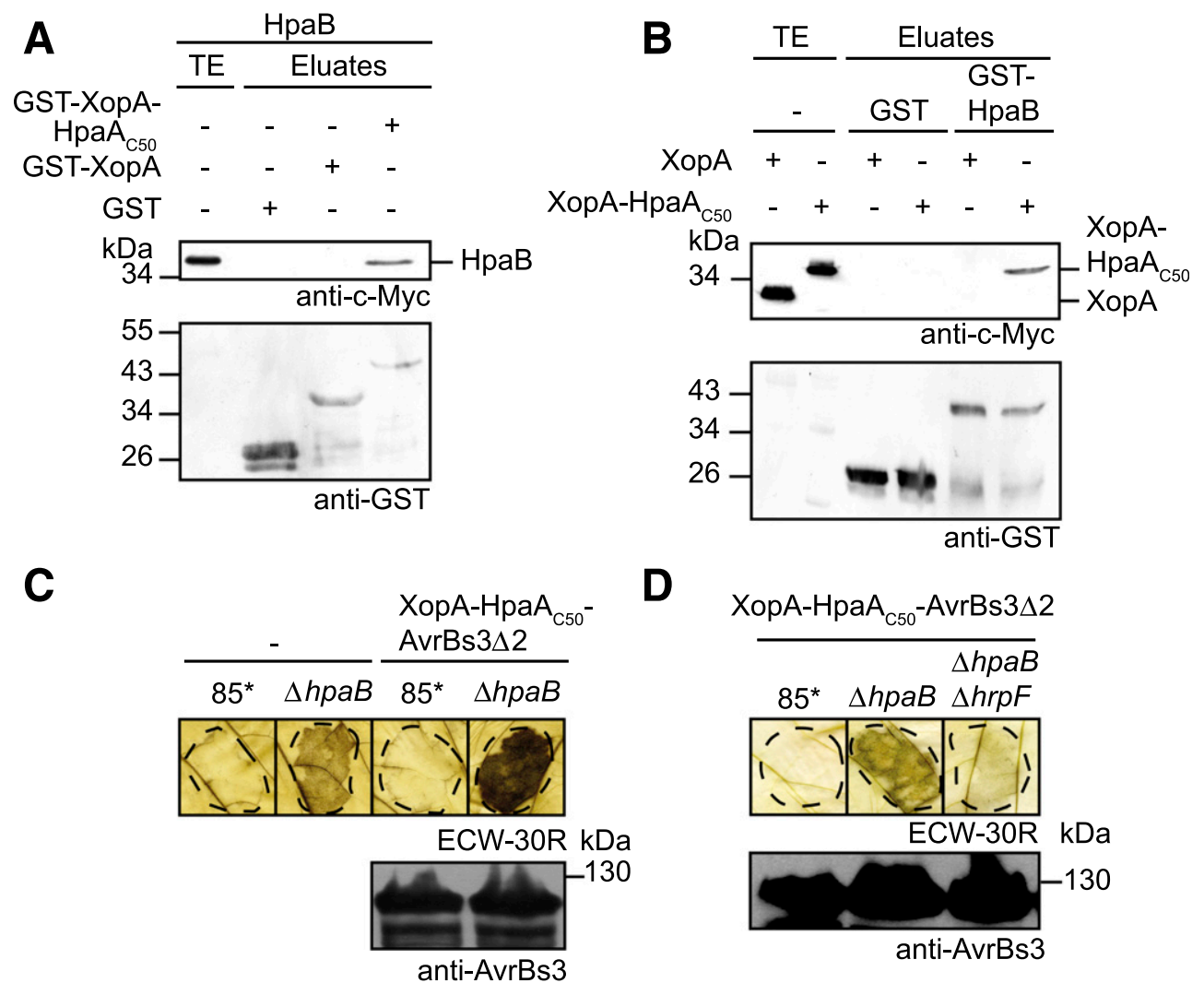

D

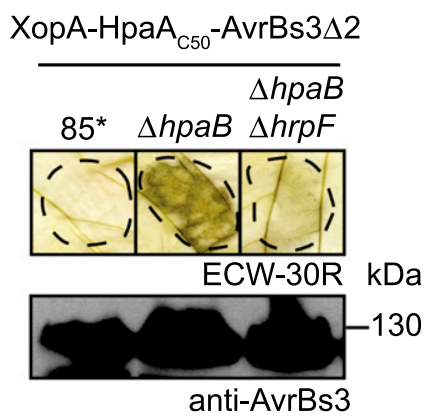

Fig. 7. XopA-HpaA $A_{C 50}$ interacts with $\mathrm{HpaB}$ and targets the AvrBs3 32 reporter for translocation in $h p a B$ deletion mutant strains. A, GST-XopA-HpaA interacts with HpaB-c-Myc in vitro. Glutathione-S-transferase (GST), GST-XopA, and GST-XopA-HpaA $\mathrm{C}_{\mathrm{C} 0}$ were immobilized on glutathione sepharose and were incubated with a bacterial cell lysate containing HpaB-c-Myc. The total cell extract (TE) and eluted proteins (eluates) were analyzed by immunoblotting,

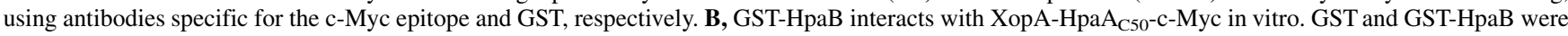
immobilized on glutathione sepharose and were incubated with bacterial lysates containing XopA-c-Myc or XopA-HpaA $50^{-c}-\mathrm{Myc}_{\mathrm{C}} \mathrm{TE}$ and eluates were analyzed as described in A. C, XopA-HpaA ${ }_{C 50^{-}}$AvrBs $3 \Delta 2$ is translocated in the absence of HpaB. Strains $85^{*}$ and $85^{*} \Delta h p a B(\Delta h p a B$ ) containing XopAAvrBs $3 \Delta 2$ or XopA-HpaA ${ }_{\mathrm{C} 50}$-AvrBs3 32 were infiltrated into leaves of AvrBs3-responsive ECW-30R pepper plants. Dashed lines indicate the infiltrated areas. Leaves were destained in ethanol 3 days postinoculation. Plant reactions in AvrBs1-responsive ECW-10R plants are shown in Supplementary Fig. S6. Equal amounts of cell extracts were analyzed by immunoblotting, using antibodies specific for AvrBs3. D, Translocation of XopA-HpaA $\mathrm{C}_{50} \mathrm{~A}_{\mathrm{Av}} \mathrm{Bs} 3 \Delta 2 \mathrm{depends}$ on the translocon protein HrpF. Strains $85^{*}, 85^{*} \Delta h p a B(\Delta h p a B)$, and $85^{*} \Delta h p a B \Delta h r p F(\Delta h p a B \Delta h r p F)$, encoding XopA-HpaA $\mathrm{C} 50^{-A v r B s} 3 \Delta 2$, were infiltrated into leaves of AvrBs3-responsive pepper plants. Plant reactions and cell extracts were analyzed as described in $\mathrm{C}$. 
bacterium Pseudomonas syringae, however, did not interfere with $\mathrm{T} 3 \mathrm{~S}$ and translocation, suggesting that the characteristic amino acids in the $\mathrm{N}$-terminal region of AvrPto are dispensable for type III-dependent delivery (Schechter et al. 2012). The analysis of amino acid compositions of XopE2 and XopJ revealed that the N-terminal 40 and 50 amino acids, respectively, contain elevated amounts of serine, proline, and threonine residues and no arginine residues (Supplementary Fig. S7). The content of other polar amino acids was not significantly changed when compared with the full-length proteins. Increased levels of serine residues, however, are also present in the N-terminal region of the cytoplasmic T3S chaperone $\mathrm{HpaB}$ and might, therefore, not be specific for $\mathrm{N}$-terminal T3S signals. The contribution of single $\mathrm{N}$-terminal amino acids to the secretion and translocation of T3S substrates from $X$. campestris pv. vesicatoria will be in the focus of future studies.

XopE2 and XopJ contain not only T3S and translocation signals but, also, minimal translocation signals in- and outside the N-terminal regions. Minimal translocation signals specifically promote translocation in the absence of $\mathrm{HpaB}$ but not in

Table 1. Summary of the results of in vitro type III secretion (T3S) and in vivo translocation assays

\begin{tabular}{|c|c|c|c|c|}
\hline \multirow[b]{2}{*}{ Protein } & \multicolumn{2}{|c|}{$\begin{array}{l}\text { Results of T3S } \\
\text { assays }^{\mathbf{a}}\end{array}$} & \multicolumn{2}{|c|}{$\begin{array}{c}\text { Results of } \\
\text { translocation } \\
\text { assays }^{b}\end{array}$} \\
\hline & $85 *$ & $85^{*} \Delta h p a B$ & $85^{*}$ & $85 * \Delta h p a B$ \\
\hline \multicolumn{5}{|l|}{ XopE2 derivatives } \\
\hline ХорЕ2-c-Мус & + & n.d. & n.d. & n.d. \\
\hline XopE2 $22_{-5}-\mathrm{c}-\mathrm{Myc}$ & + & n.d. & n.d. & n.d. \\
\hline ХорЕ $2_{\Delta 2-10^{-c}-\mathrm{Myc}}$ & - & n.d. & n.d. & n.d. \\
\hline $\mathrm{XopE} 2_{\Delta 9-13-\mathrm{c}-\mathrm{Myc}^{\mathrm{c}}}$ & - & n.d. & n.d. & n.d. \\
\hline XopE2-AvrBs3 $3 \Delta 2$ & + & n.d. & + & $(+)$ \\
\hline XopE2 20 -AvrBs $3 \Delta 2$ & + & n.d. & _- & - \\
\hline XopE2 ${ }_{1-30}-\operatorname{AvrBs} 3 \Delta 2$ & + & n.d. & _- & - \\
\hline XopE2 $2_{1-40}-A v r B s 3 \Delta 2$ & + & n.d. & - & + \\
\hline XopE2 $1-50-A v r B s 3 \Delta 2$ & + & n.d. & - & - \\
\hline XopE2 $_{1-150}-A v r B s 3 \Delta 2$ & + & n.d. & + & $(+)$ \\
\hline XopE2 & n.d. & n.d. & - & + \\
\hline \multicolumn{5}{|l|}{ XopJ derivatives } \\
\hline XopJ-c-Myc & + & n.d. & n.d. & n.d. \\
\hline $\mathrm{XopJ}_{\Delta 2-5-\mathrm{c}-\mathrm{Myc}}$ & $(+)$ & n.d. & n.d. & n.d. \\
\hline $\mathrm{XopJ}_{\Delta 2-10^{-}-\mathrm{c}-\mathrm{Myc}}$ & - & n.d. & n.d. & n.d. \\
\hline $\mathrm{XopJ}_{\triangle 9-13}-\mathrm{c}-\mathrm{Myc}$ & + & n.d. & n.d. & n.d. \\
\hline XopJ-AvrBs3 $3 \Delta 2$ & + & n.d. & + & - \\
\hline $\mathrm{XopJ}_{1-50}-\mathrm{AvrBs}_{3} \Delta 2$ & + & n.d. & - & + \\
\hline $\mathrm{XopJ}_{\Delta 2-50}-\operatorname{AvrBs} 3 \Delta 2$ & n.d. & n.d. & - & + \\
\hline \multicolumn{5}{|l|}{ XорA derivatives } \\
\hline ХорА-c-Мус & + & n.d. & n.d. & n.d. \\
\hline $\mathrm{XopA}_{\Delta 2-5-\mathrm{c}-\mathrm{Myc}}$ & $(+)$ & n.d. & n.d. & n.d. \\
\hline XopA $_{\Delta 2-10^{-c}-M y c}$ & - & n.d. & n.d. & n.d. \\
\hline $\mathrm{XopA}_{\Delta 2-21^{-}-\mathrm{c}-\mathrm{Myc}}$ & - & n.d. & n.d. & n.d. \\
\hline XopA-AvrBs3 $3 \Delta 2$ & n.d. & n.d. & - & + \\
\hline $\mathrm{XopA}_{1-20}-\mathrm{AvrBs}_{3} \Delta 2$ & + & + & - & - \\
\hline XopA $_{1-25}-$ AvrBs $3 \Delta 2$ & + & + & - & - \\
\hline $\mathrm{XopA}_{1-30}-\operatorname{AvrBs} 3 \Delta 2$ & + & + & - & + \\
\hline $\mathrm{XopA}_{\triangle 2-5}-\mathrm{AvrBs}_{3} \Delta 2$ & n.d. & n.d. & - & + \\
\hline 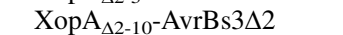 & n.d. & n.d. & - & - \\
\hline $\mathrm{XopA}_{\Delta 2-21}$-AvrBs3 $3 \Delta 2$ & n.d. & n.d. & - & - \\
\hline XopA-HpaA ${ }_{C 50}-A v r B s 3 \Delta 2$ & n.d. & n.d. & - & + \\
\hline \multicolumn{5}{|c|}{$\begin{array}{l}\text { a Proteins were analyzed as C-terminal c-Myc epitope-tagged derivatives } \\
\text { for in vitro T3S in } X \text {. campestris pv. vesicatoria strains } 85^{*} \text { and } \\
85^{*} \Delta h p a B . \text { n.d. }=\text { not determined, }+=\text { secreted, }-=\text { secretion not } \\
\text { detectable, }(+)=\text { reduced secretion. } \\
\text { b Proteins were analyzed for in vivo translocation as } \mathrm{N} \text {-terminal fusion } \\
\text { partners of the AvrBs } 3 \Delta 2 \text { reporter. }+=\text { translocation, }-=\text { no translocation } \\
\text { observed, }(+)=\text { reduced translocation. } \\
\text { c Reduced amounts of XopE } 2_{\Delta 9-13^{-c-M y c} \text { were detected in the cell extracts }} \\
\text { when compared with XopE2-c-Myc. }\end{array}$} \\
\hline
\end{tabular}

the wild-type strain and were previously identified in the noneffectors XopA and HrpF (Büttner et al. 2004). It was, therefore, speculated that $\mathrm{HrpF}$ and XopA are translocated prior to the HpaA-mediated activation of HpaB. Similarly, the presence of minimal translocation signals in effector proteins might promote their translocation before the activation of HpaB. Notably, however, despite the presence of minimal translocation signals, the full-length XopJ protein is not translocated in the absence of $\mathrm{HpaB}$ (Fig. 4). Previous in vivo translocation assays already revealed that effector proteins likely differ in their HpaB-dependent translocation. Thus, some effectors, including XopE2, are translocated by $h p a B$ deletion mutants, albeit in reduced amounts (Büttner et al. 2006; Schulze et al. 2012). Similar findings were reported for effectors from the related pathogen Ralstonia solanacearum (Lonjon et al. 2016). The HpaB-independent secretion and translocation of effectors is indicative of a temporal regulation of effector delivery. Thus, it was speculated that HpaB-independent effectors are translocated during early stages of the host-pathogen interaction (Büttner et al. 2006). A hierarchy in effector protein delivery was previously reported for animal-pathogenic bacteria (Enninga et al. 2005; Mills et al. 2008; Schlumberger et al. 2005; VanEngelenburg and Palmer 2008; Winnen et al. 2008) and might be achieved by differences in the expression of effector genes, specific export signals, or different affinities of effector-chaperone complexes to the T3S system (Deng et al. 2017; Sorg et al. 2007).

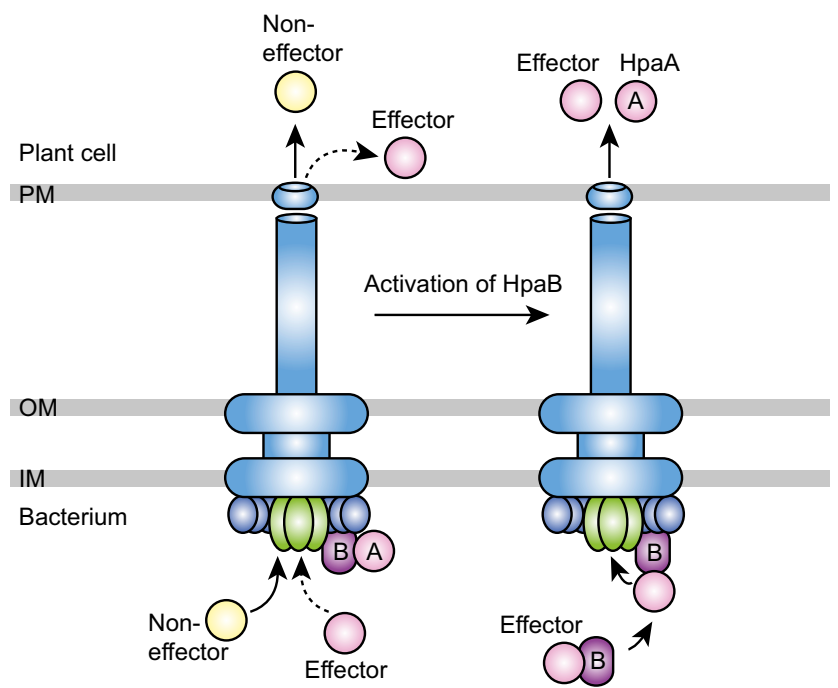

Fig. 8. Model of the HpaB-mediated control of protein translocation in Xanthomonas campestris pv. vesicatoria. The type III secretion (T3S) system consists of a membrane-spanning secretion apparatus and is associated with an extracellular pilus and a translocon in the plant plasma membrane. T3S substrates include extracellular components of the secretion apparatus, such as pilus and translocon proteins, which contain T3S and minimal translocation signals and are referred to as noneffectors. Noneffectors are secreted after the assembly of the membrane-spanning secretion apparatus and are, presumably, translocated into the plant cell in the absence of an active $\mathrm{HpaB}$ chaperone (indicated as $\mathrm{B}$ ). HpaB associates with the T3S system and is activated after a switch in T3S substrate specificity upon secretion and translocation of its regulator $\mathrm{HpaA}$ (indicated as A). The activation of $\mathrm{HpaB}$ allows the recognition of translocation signals and, thus, the translocation of effector proteins into the plant cell. Given that HpaB interacts with effectors and components of the T3S system, it was proposed to act as an escort protein that targets effectors to the secretion apparatus. Notably, however, some effectors are even translocated before the activation of $\mathrm{HpaB}$, albeit in reduced amounts (indicated by a dashed arrow). Activation of $\mathrm{HpaB}$ upon secretion of HpaA suppresses the recognition of minimal translocation signals by the T3S system. The model suggests a role of $\mathrm{HpaB}$ in the recognition of translocation signals in addition to its predicted function as an escort protein. $\mathrm{IM}=$ inner membrane, $\mathrm{OM}=$ outer membrane, and PM = plasma membrane of plant cell. 
T3S chaperones including $\mathrm{HpaB}$ from $X$. campestris $\mathrm{pv}$. vesicatoria were previously reported to interact with effectors and components of the T3S system and were proposed to act as escort proteins that target effectors to the secretion apparatus (Büttner 2012; Chen et al. 2013; Thomas et al. 2012). However, given our finding that $\mathrm{N}$-terminal deletion derivatives of XopE2 and XopJ, which interact with $\mathrm{HpaB}$, are not translocated by the wild-type strain, the interaction of XopE2 and XopJ with HpaB is presumably not sufficient for translocation. In agreement with this finding, the presence of a HpaB-binding site did not promote translocation of XopA in the wild-type strain (Fig. 7). Our translocation assays revealed that $\mathrm{HpaB}$ suppresses the translocation of XopA fusion proteins or N-terminal deletion derivatives of XopE2 and XopJ, despite its interaction with these proteins (Figs. 4 and 7). Therefore, we assume that the HpaB-mediated control of translocation is determined by the export signal and not by the presence of a $\mathrm{HpaB}$-binding site. Thus, HpaB likely controls the recognition of translocation signals independently of its interaction with T3S substrates. In line with this hypothesis, we previously reported that the deletion of the HpaB-binding site in $\mathrm{HpaA}$ did not affect its HpaB-dependent secretion (Lorenz et al. 2008a). HpaB might be directly involved in the recognition of translocated proteins at the secretion apparatus, possibly by controlling a yet-unknown substrate acceptor site at the inner membrane that is specific for translocated proteins when associated with HpaB (Fig. 8). The absence of $\mathrm{HpaB}$ would thus allow the alternative recognition of minimal translocation signals.

One known T3S substrate docking site is the putative $\mathrm{C}$ ring protein $\mathrm{HrcQ}$, which interacts with $\mathrm{T} 3 \mathrm{~S}$ substrates and $\mathrm{HpaB}$ (Lorenz et al. 2012). The results of our interaction studies revealed that HrcQ interacts with $\mathrm{N}$-terminal deletion derivatives of XopE2 and XopJ, suggesting that the T3S signal is dispensable for the targeting of $\mathrm{T} 3 \mathrm{~S}$ substrates to the predicted $\mathrm{C}$ ring. Similar findings were previously reported for the interaction of the effector protein AvrBs3 with HrcQ as well as with the cytoplasmic domain of the inner membrane protein $\mathrm{HrcV}$, which is a component of the export apparatus (Hartmann and Büttner 2013; Lorenz et al. 2012). In line with these observations, T3S signals were previously reported to be dispensable for the interaction of chaperone-effector complexes with the ATPase of the T3S system (Chen et al. 2013; Rodgers et al. 2008). Translocation signals might, therefore, be recognized after the initial binding of T3S substrates to components of the T3S system, presumably upon activation of $\mathrm{HpaB}$. In summary, our data suggest that the $\mathrm{T} 3 \mathrm{~S}$ chaperone $\mathrm{HpaB}$ is involved in the recognition of translocation signals independently of its predicted role as an escort protein for effector proteins. The identification of specific recognition sites of the T3S system for secretion and translocation signals remains a challenging topic for future studies.

\section{MATERIALS AND METHODS}

\section{Bacterial strains and growth conditions.}

Bacterial strains and plasmids are listed in Table 2. Escherichia coli was cultivated at $37^{\circ} \mathrm{C}$ in lysogeny broth, $X$. campestris pv. vesicatoria and Agrobacterium tumefaciens strains at $30^{\circ} \mathrm{C}$ in nutrient-yeast extract-glycerol (NYG) medium (Daniels et al. 1984). For the analysis of in vitro T3S, X. campestris pv. vesicatoria was grown in minimal medium A (Ausubel et al. 1996) supplemented with sucrose (10 $\mathrm{mM}$ final concentration) and casamino acids ( $0.3 \%$ final concentration).

\section{Plant material and plant inoculations.}

Infection assays were performed with $X$. campestris pv. vesicatoria strains and the near-isogenic pepper cultivars ECW-10R and ECW-30R, which contain $B s 1$ and $B s 3$ resistance genes, respectively. Bacteria were resuspended in $1 \mathrm{mM} \mathrm{MgCl} 2$ and were infiltrated at concentrations of $4 \times 10^{8} \mathrm{CFU} \mathrm{ml}^{-1}$, if not stated otherwise (Bonas et al. 1991; Kousik and Ritchie 1998; Minsavage et al. 1990). After infection, pepper plants were incubated for day cycles of $16 \mathrm{~h}$ of light at $28^{\circ} \mathrm{C}$ and $65 \%$ humidity and $8 \mathrm{~h}$ of darkness at $22^{\circ} \mathrm{C}$ and $65 \%$ humidity. The appearance of plant reactions was scored over a period of 1 to 3 days postinoculation. For the better visualization of the HR, leaves were destained in $70 \%$ ethanol. For each experiment, representative plant reactions, which were reproduced at least twice in independent experiments, are shown. For each construct, experiments were always performed with at least two different $X$. campestris pv. vesicatoria transformants, obtained by at least two independent conjugations or electroporations. Agrobacterium tumefaciens strains were resuspended in $1 \mathrm{mM} \mathrm{MgCl} l_{2}$ and were infiltrated at a density of $8 \times 10^{8} \mathrm{CFU} \mathrm{ml} \mathrm{m}^{-1}$ into leaves of ECW-10R and ECW$30 \mathrm{R}$ pepper plants.

\section{Conjugation and electroporation of plasmids into $X$. campestris pv. vesicatoria.}

Plasmids were introduced into $X$. campestris pv. vesicatoria by conjugation or electroporation. For conjugations, pRK2013 was used as a helper plasmid in triparental matings (Figurski and Helinski 1979). For electroporation of plasmids into X. campestris pv. vesicatoria, bacteria were resuspended in cold sterile water at a density of $10^{8} \mathrm{CFU} \mathrm{m}{ }^{-1}$, were washed three times with 1 volume of ice-cold water, and were resuspended in $50 \mu \mathrm{l}$ of sterile $10 \%$ glycerol. Plasmid DNA (50 to $100 \mathrm{ng}$ ) was electroporated at a voltage of $2.5 \mathrm{kV}$. After addition of $400 \mu \mathrm{l}$ of NYG medium, cells were plated on NYG agar plates with appropriate antibiotics. The stable synthesis of fusion proteins was analyzed by immunoblot analysis of cell extracts of at least three different transformants.

\section{Generation of expression constructs.}

For the generation of expression constructs encoding C-terminally c-Myc epitope-tagged derivatives of XopA, XopE2, and XopJ, corresponding gene fragments were amplified by polymerase chain reaction (PCR) from $X$. campestris pv. vesicatoria 85-10 and were cloned into the $B s a \mathrm{I}$ sites of plasmid pBRM via Golden Gate cloning (Engler et al. 2008). pBRM is a derivative of the broad-host range vector pBBRMCS-5 and contains the lac promoter, the lacZ alpha fragment flanked by BsaI sites, and a triple c-Myc epitope-encoding sequence (Szczesny et al. 2010) (Table 2). To obtain a $x o p A-h p a A_{C 50^{-c}-m y c}$ expression construct, $x o p A$ and $h p a A_{C 50}$ were individually amplified by PCR, using primers with $B s a \mathrm{I}$ recognition sites. The overhangs resulting from $B s a \mathrm{I}$ digestion allowed the unidirectional ligation of both gene fragments into pBRM in a single restriction-ligation reaction. For the generation of an expression construct encoding GST-XopA$\mathrm{HpaA}_{\mathrm{C} 50}, x о p A$ and $h p a A_{C 50}$ were amplified by PCR and were cloned into the EcoRI and XhoI sites of plasmid pGEX-2TKM. The pBRM derivative encoding XopE $2_{\Delta 9-13^{-c}-M y c}$ was generated by PCR, using pBxopE2 as template and phosphorylated primers annealing back to back to the flanking regions of the deletion. Similarly, $\mathrm{pBxopJ}_{\Delta 9-13}$ was generated by PCR amplification of pBxopJ, using primers that annealed to the flanking regions of the deletion and contained a $B s a \mathrm{I}$ site with a complementary overhang.

All constructs encoding AvrBs $3 \Delta 2$ fusion proteins under control of the lac promoter are derivatives of plasmid pBR356, which contains the lac promoter, the lacZ alpha fragment flanked by $B s a \mathrm{I}$ sites, and the $a v r B s 3 \Delta 2$ reporter gene (Scheibner et al. 2016). Gene fragments encoding the AvrBs $3 \Delta 2$ fusion partners were amplified by PCR and were cloned into the $B s a \mathrm{I}$ sites of pBR356 in a Golden Gate cloning reaction.

To obtain an expression construct encoding $\mathrm{XopA}_{1-30^{-}}$ AvrBs $3 \Delta 2$ under control of the native xopA promoter, $678 \mathrm{bp}$ 
upstream and the first 30 codons of xopA were amplified by PCR. The PCR product was cloned into the EcoRI site of plasmid pBS356F, which contains avrBs3 42 . The resulting insert was subsequently excised via EcoRI and HindIII digestion and was cloned into pLAFR6, giving pL6xopA $1-30-356$.
For the generation of a binary expression construct, xopE2 $2_{1-50}$ was amplified by PCR and was ligated with modules encoding $\mathrm{N}$-terminal, central, and C-terminal regions of AvrBs $3 \Delta 2$ into the binary vector pGGA3 downstream of the $35 S$ promoter. The primers used in this study are listed in Supplementary Table S1.

Table 2. Bacterial strains and plasmids used in this study

\begin{tabular}{|c|c|c|}
\hline Strain or plasmid & Relevant characteristics $^{\mathbf{a}}$ & Reference or source \\
\hline \multicolumn{3}{|c|}{ Xanthomonas campestris pv. vesicatoria } \\
\hline $85-10$ & Pepper-race 2 ; wild type; Rif $^{\mathrm{r}}$ & Canteros 1990; Kousik and Ritchie 1998 \\
\hline $85^{*}$ & 85-10 derivative containing the $h r p G^{*}$ mutation & Wengelnik et al. 1999 \\
\hline $85^{*} \Delta h p a B$ & hpaB deletion mutant of strain $85^{*}$ & Büttner et al. 2004 \\
\hline 85-10 $\Delta$ hpaB & hpaB deletion mutant of strain $85-10$ & Büttner et al. 2004 \\
\hline $85^{*} \Delta h p a B \Delta h r p F$ & hpaB/hrpF deletion mutant of strain $85^{*}$ & Büttner et al. 2004 \\
\hline \multicolumn{3}{|l|}{ Agrobacterium tumefaciens } \\
\hline GV2260 & Contains Ti plasmid pGV2260, Rif $^{\mathrm{r}}, \mathrm{Ap}^{\mathrm{r}}$ & Deblaere et al. 1985 \\
\hline \multicolumn{3}{|l|}{ Escherichia coli } \\
\hline $\mathrm{DH} 5 \alpha$ & $\mathrm{F}^{-}$recA $h s d R 17\left(r_{k}^{-}, m_{k}^{+}\right) \Phi 80 d l a c Z$ DM15 & $\begin{array}{l}\text { Bethesda Research Laboratories, Bethesda, MD, } \\
\text { U.S.A. }\end{array}$ \\
\hline DH5 $\alpha \lambda$ pir & 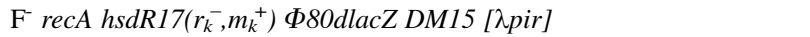 & Ménard et al. 1993 \\
\hline BL21(DE3) & 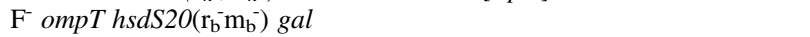 & Stratagene, Heidelberg, Germany \\
\hline \multicolumn{3}{|l|}{ Plasmids } \\
\hline pBBR1MCS-5 & Broad-host-range vector; lac promoter; $\mathrm{Gm}^{\mathrm{r}}$ & Kovach et al. 1995 \\
\hline pBRM & Golden Gate-compatible derivative of pBBR1MCS-5 & Szczesny et al. 2010 \\
\hline pBR356 & $\begin{array}{l}\text { Derivative of pBBR1MCS-5 containing } a v r B s 3 \Delta 2 \text { downstream of the } \\
\text { lac promoter and the lacZ } \alpha \text { fragment, which is flanked by } B s a \text { I sites }\end{array}$ & Scheibner et al. 2016 \\
\hline pBS356F & Derivative of pBluescript(II) KS containing $a v r B s 3 \Delta 2$ & Büttner et al. 2004 \\
\hline pGEX-2TKM & $\begin{array}{l}\text { GST expression vector; } \mathrm{p}_{t a c} \text { GST lacI }{ }^{\mathrm{q}} \mathrm{pBR} 322 \text { ori; } \mathrm{Ap}^{\mathrm{r}} \text {, derivative of } \\
\text { pGEX-2TK with polylinker of pDSK604 }\end{array}$ & Stratagene; Escolar et al. 2001 \\
\hline pLAFR6 & $\begin{array}{l}\text { RK2 replicon, } \mathrm{Mob}^{+} \mathrm{Tra}^{-} \text {, multicloning site flanked by transcription } \\
\text { terminators; } \mathrm{Tc}^{\mathrm{r}}\end{array}$ & Bonas et al. 1989 \\
\hline pRK2013 & ColE1 replicon, $\mathrm{TraRK}^{+} \mathrm{Mob}^{+} ; \mathrm{Km}^{\mathrm{r}}$ & Figurski and Helinski 1979 \\
\hline pUC57 $\triangle \mathrm{BsaI}$ & Derivative of pUC57 with mutated $B s a$ I site & Morbitzer et al. 2011 \\
\hline $\mathrm{pBxopA}_{1-20^{-}} 356$ & Derivative of pBR356 encoding $\mathrm{XopA}_{1-20}$-AvrBs $3 \Delta 2$ & This study \\
\hline pBxopA $A_{1-25}-356$ & Derivative of pBR356 encoding $\mathrm{XopA}_{1-25}-\mathrm{AvrBs}_{3} \Delta 2$ & This study \\
\hline $\mathrm{pBxopA}_{1-30}-356$ & Derivative of pBR356 encoding $\mathrm{XopA}_{1-30}$-AvrBs $3 \Delta 2$ & This study \\
\hline $\mathrm{pBxopA}_{\Delta 2-5}-356$ & Derivative of pBR356 encoding $\mathrm{XopA}_{\Delta 2-5^{-}}$-AvrBs $3 \Delta 2$ & This study \\
\hline pBxopA $_{\Delta 2-10^{-}} 356$ & Derivative of pBR356 encoding $\mathrm{XopA}_{\Delta 2-10^{-}}$AvrBs $3 \Delta 2$ & This study \\
\hline pBxopA $_{\Delta 2-21-356}$ & Derivative of pBR356 encoding $\mathrm{XopA}_{\Delta 2-21}$-AvrBs $3 \Delta 2$ & This study \\
\hline $\mathrm{pBxopA}_{\mathrm{FL}}-356$ & Derivative of pBR356 encoding $\mathrm{XopA}_{\mathrm{FL}}-\mathrm{AvrBs} 3 \Delta 2$ & This study \\
\hline pBxopAhpaA ${\mathrm{C} 50^{-}-356}$ & Derivative of $\mathrm{pBR} 356$ encoding XopA-HpaA $\mathrm{C}_{\mathrm{C} 0}$-AvrBs $3 \Delta 2$ & This study \\
\hline pBRMxopA & Derivative of pBRM encoding XopA-c-Myc & Lorenz and Büttner 2011 \\
\hline pBRMxopA $_{\Delta 2-5}$ & Derivative of $\mathrm{pBRM}$ encoding $\mathrm{XopA}_{\Delta 2-5}-\mathrm{c}-\mathrm{Myc}$ & This study \\
\hline pBRMxopA $_{\Delta 2-10}$ & Derivative of $\mathrm{pBRM}$ encoding $\mathrm{XopA}_{\Delta 2-10^{-} \mathrm{c}-\mathrm{Myc}}$ & This study \\
\hline $\mathrm{pBRMxopA}_{\Delta 2-21}$ & Derivative of pBRM encoding $\mathrm{XopA}_{\Delta 2-21}$-c-Myc & This study \\
\hline pBRMxopAhpaA $\mathrm{C} 50$ & Derivative of $\mathrm{pBRM}$ encoding XopA-HpaA $\mathrm{C}_{\mathrm{C} 0^{-}} \mathrm{c}-\mathrm{Myc}$ & This study \\
\hline pBRMxopE2 & Derivative of pBRM encoding XopE2-c-Myc & Lorenz and Büttner 2011 \\
\hline pBRMxopE2 $2_{\Delta 2-5}$ & Derivative of pBRM encoding XopE $2_{\Delta 2-5}-\mathrm{c}-\mathrm{Myc}$ & This study \\
\hline pBRMxopE2 $2_{\Delta 2-10}$ & Derivative of $\mathrm{pBRM}$ encoding XopE $2_{\Delta 2-10^{-c}-\mathrm{Myc}}$ & This study \\
\hline pBRMxopE2 $2_{\Delta 9-13}$ & Derivative of $\mathrm{pBRM}$ encoding XopE $2_{\Delta 9-13}-\mathrm{c}-\mathrm{Myc}$ & This study \\
\hline pBxopE2 $1-20-356$ & Derivative of $\mathrm{pBRM}$ encoding XopE $2_{1-20}$-AvrBs $3 \Delta 2$ & This study \\
\hline pBxopE2 $2-30^{-356}$ & Derivative of pBRM encoding XopE2 $2-30$-AvrBs $3 \Delta 2$ & This study \\
\hline pBxopE2 $1-40^{-} 356$ & Derivative of pBRM encoding XopE2 $2-40$-AvrBs $3 \Delta 2$ & This study \\
\hline pBxopE2 $1-50^{-356}$ & Derivative of pBRM encoding XopE $2{ }_{1-50}$-AvrBs $3 \Delta 2$ & This study \\
\hline pBxopE2 $2-150-356$ & Derivative of pBRM encoding XopE2 $2_{1-150}$-AvrBs $3 \Delta 2$ & This study \\
\hline $\mathrm{pB} \times \mathrm{xpE} 22_{\mathrm{FL}}-356$ & Derivative of $\mathrm{pBRM}$ encoding $\mathrm{XopE} 2{ }_{\mathrm{FL}}-\operatorname{AvrBs} 3 \Delta 2$ & This study \\
\hline pBxopE $2_{\Delta 2-40^{-}}-356$ & Derivative of pBRM encoding XopE $2_{\Delta 2-40^{-}}$AvrBs $3 \Delta 2$ & This study \\
\hline pBRMxopJ & Derivative of pBRM encoding XopJ-c-Myc & Lorenz and Büttner 2011 \\
\hline pBRMxopJ $_{\Delta 2-5}$ & Derivative of $\mathrm{pBRM}$ encoding $\mathrm{XopJ}_{\Delta 2-5}-\mathrm{c}-\mathrm{Myc}$ & This study \\
\hline $\mathrm{pBRMxopJ}_{\Delta 2-10}$ & Derivative of $\mathrm{pBRM}$ encoding $\mathrm{XopJ}_{\Delta 2-10^{-} \mathrm{c}-\mathrm{Myc}}$ & This study \\
\hline pBRMxopJ $_{\Delta 9-13}$ & Derivative of pBRM encoding $\mathrm{XopJ}_{\Delta 9-13-\mathrm{c}-\mathrm{Myc}}$ & This study \\
\hline $\mathrm{pBxopJ}_{1-50^{-}} 356$ & Derivative of pBRM encoding $\mathrm{XopJ}_{1-50^{-}}$AvrBs $3 \Delta 2$ & This study \\
\hline $\mathrm{pBxopJ}_{\mathrm{FL}}-356$ & Derivative of pBRM encoding $\mathrm{XopJ}_{\mathrm{FL}}-\mathrm{AvrBs}_{3} \Delta 2$ & This study \\
\hline pBxopJ $_{\Delta 2-50-356}$ & Derivative of $\mathrm{pBRM}$ encoding $\mathrm{XopJ}_{\Delta 2-50}-\operatorname{AvrBs} 3 \Delta 2$ & This study \\
\hline pDhpaB & Derivative of plasmid pDSK604 encoding HpaB-c-Myc & Büttner et al. 2004 \\
\hline pGGA3xopE2 $2{ }_{1-50^{-}} 356$ & $\begin{array}{l}\text { Binary vector containing } x o p E 2_{1-50^{-}}-a v r B s 3 \Delta 2 \text { downstream of the } 35 S \\
\text { promoter }\end{array}$ & This study; S. Thieme and U. Bonas, unpublished \\
\hline pGhpaB & pGEX-2TKM derivative encoding GST-HpaB & This study \\
\hline pGxopA & pGEX-2TKM derivative encoding GST-XopA & Büttner et al. 2004 \\
\hline pGxopAhpaA $A_{C 50}$ & pGEX-2TKM derivative encoding GST-XopA-HpaA ${ }_{\mathrm{C} 50}$ & This study \\
\hline pL6xopA $1-30-356$ & $\begin{array}{l}\text { Derivative of pLAFR6 encoding } \mathrm{XopA}_{1-30}-\mathrm{AvrBs}_{3} \Delta 2 \text { under control of } \\
\text { the native } \text { xopA promoter }\end{array}$ & This study \\
\hline
\end{tabular}

\footnotetext{
${ }^{\mathrm{a}} \mathrm{Ap}=$ ampicillin, $\mathrm{Km}=$ kanamycin, $\mathrm{Rif}=$ rifampicin, $\mathrm{Sm}=$ spectinomycin, $\mathrm{Tc}=$ tetracycline, ${ }^{\mathrm{r}}=$ resistant.
} 


\section{Preparation of protein extracts and in vitro secretion assays.}

For the analysis of protein synthesis, bacteria were cultivated overnight in liquid NYG medium and cells were harvested by centrifugation. Equal amounts of proteins adjusted according to the optical density of the culture were analyzed by immunoblotting, using AvrBs3-specific antibodies (Knoop et al. 1991). Secretion assays were performed in minimal medium $\mathrm{A}(\mathrm{pH}$ 5.3) in the presence of BSA and thiamine, as described previously (Rossier et al. 1999). Equal amounts of bacterial total cell extracts and culture supernatants (adjusted according to the optical density of the cultures) were analyzed by sodium dodecyl sulfate-polyacrylamide gel electrophoresis (SDS-PAGE) and immunoblotting, using antibodies specific for the c-Myc epitope (Roche), GST (Amersham Pharmacia), AvrBs3, the predicted inner membrane ring protein $\mathrm{HrcJ}$, the predicted periplasmic inner rod protein HrpB1, and the secreted translocon protein HrpF, as indicated (Büttner et al. 2002; Knoop et al. 1991; Rossier et al. 2000). Horseradish peroxidase-labeled antirabbit or antimouse antibodies (GE Healthcare) were used as secondary antibodies. Results were reproduced at least twice in independent experiments.

\section{GST pull-down assays.}

GST pull-down assays were performed as described previously (Hartmann et al. 2012). Briefly, E. coli cells containing GST or GST fusion proteins were broken with a French press and cell debris were removed by centrifugation. GST and GST fusion proteins were immobilized on glutathione sepharose and were incubated with $E$. coli lysates containing the putative interaction partner. Unbound proteins were removed by washing steps and proteins were eluted with $10 \mathrm{mM}$ reduced glutathione. Total protein lysates and eluted proteins were analyzed by SDS-PAGE and immunoblotting, using antibodies specific for the c-Myc epitope and GST (Roche Applied Science), respectively. Results were reproduced at least twice in independent experiments.

\section{ACKNOWLEDGMENTS}

We are grateful to U. Bonas for helpful comments on the manuscript and for providing the AvrBs3-specific antibody and to M. Jordan for technical assistance. This work was supported by grants from the Deutsche Forschungsgemeinschaft (BU2145/5-1 and CRC 648 "Molecular mechanisms of information processing in plants") to D. Büttner.

\section{LITERATURE CITED}

Akeda, Y., and Galán, J. E. 2005. Chaperone release and unfolding of substrates in type III secretion. Nature 437:911-915.

Allen-Vercoe, E., Toh, M. C., Waddell, B., Ho, H., and DeVinney, R. 2005. A carboxy-terminal domain of Tir from enterohemorrhagic Escherichia coli O157:H7 (EHEC O157:H7) required for efficient type III secretion. FEMS Microbiol. Lett. 243:355-364.

Anderson, D. M., and Schneewind, O. 1997. A mRNA signal for the type III secretion of Yop proteins by Yersinia enterocolitica. Science 278:1140-1143.

Anderson, D. M., and Schneewind, O. 1999. Yersinia enterocolitica type III secretion: An mRNA signal that couples translation and secretion of YopQ. Mol. Microbiol. 31:1139-1148.

Arnold, R., Brandmaier, S., Kleine, F., Tischler, P., Heinz, E., Behrens, S., Niinikoski, A., Mewes, H. W., Horn, M., and Rattei, T. 2009. Sequencebased prediction of type III secreted proteins. PLoS Pathog. 5:e1000376.

Ausubel, F. M., Brent, R., Kingston, R. E., Moore, D. D., Seidman, J. G., Smith, J. A., and Struhl, K., eds. 1996. Current Protocols in Molecular Biology. John Wiley \& Sons, Inc., New York.

Blocker, A., Jouihri, N., Larquet, E., Gounon, P., Ebel, F., Parsot, C., Sansonetti, P., and Allaoui, A. 2001. Structure and composition of the Shigella flexneri 'needle complex', a part of its type III secreton. Mol. Microbiol. 39:652-663.

Boch, J., and Bonas, U. 2010. Xanthomonas AvrBs3 family-type III effectors: Discovery and function. Annu. Rev. Phytopathol. 48:419-436.
Boch, J., Scholze, H., Schornack, S., Landgraf, A., Hahn, S., Kay, S., Lahaye, T., Nickstadt, A., and Bonas, U. 2009. Breaking the code of DNA binding specificity of TAL-type III effectors. Science 326:1509-1512.

Bonas, U., Schulte, R., Fenselau, S., Minsavage, G. V., Staskawicz, B. J., and Stall, R. E. 1991. Isolation of a gene-cluster from Xanthomonas campestris pv. vesicatoria that determines pathogenicity and the hypersensitive response on pepper and tomato. Mol. Plant-Microbe Interact. 4:81-88.

Bonas, U., Stall, R. E., and Staskawicz, B. 1989. Genetic and structural characterization of the avirulence gene avrBs3 from Xanthomonas campestris pv. vesicatoria. Mol. Gen. Genet. 218:127-136.

Buchko, G. W., Niemann, G., Baker, E. S., Belov, M. E., Smith, R. D., Heffron, F., Adkins, J. N., and McDermott, J. E. 2010. A multi-pronged search for a common structural motif in the secretion signal of Salmonella enterica serovar Typhimurium type III effector proteins. Mol. Biosyst. 6: 2448-2458.

Büttner, D. 2012. Protein export according to schedule: Architecture, assembly, and regulation of type III secretion systems from plant- and animal-pathogenic bacteria. Microbiol. Mol. Biol. Rev. 76:262-310.

Büttner, D. 2016. Behind the lines-actions of bacterial type III effector proteins in plant cells. FEMS Microbiol. Rev. 40:894-937.

Büttner, D., and Bonas, U. 2010. Regulation and secretion of Xanthomonas virulence factors. FEMS Microbiol. Rev. 34:107-133.

Büttner, D., Gürlebeck, D., Noël, L. D., and Bonas, U. 2004. HpaB from Xanthomonas campestris pv. vesicatoria acts as an exit control protein in type III-dependent protein secretion. Mol. Microbiol. 54:755-768.

Büttner, D., Lorenz, C., Weber, E., and Bonas, U. 2006. Targeting of two effector protein classes to the type III secretion system by a HpaC- and HpaB-dependent protein complex from Xanthomonas campestris pv. vesicatoria. Mol. Microbiol. 59:513-527.

Büttner, D., Nennstiel, D., Klüsener, B., and Bonas, U. 2002. Functional analysis of $\mathrm{HrpF}$, a putative type III translocon protein from Xanthomonas campestris pv. vesicatoria. J. Bacteriol. 184:2389-2398.

Canteros, B. I. 1990. Diversity of plasmids and plasmid-encoded phenotypic traits in Xanthomonas campestris pv. vesicatoria. Ph.D. thesis. University of Florida, Gainesville, FL, U.S.A.

Chen, L., Ai, X., Portaliou, A. G., Minetti, C. A., Remeta, D. P., Economou, A., and Kalodimos, C. G. 2013. Substrate-activated conformational switch on chaperones encodes a targeting signal in type III secretion. Cell Reports 3:709-715.

Chiu, H. J., Lin, W. S., and Syu, W. J. 2003. Type III secretion of EspB in enterohemorrhagic Escherichia coli O157:H7. Arch. Microbiol. 180:218-226.

Dangl, J. L., and Jones, J. D. G. 2001. Plant pathogens and integrated defence responses to infection. Nature 411:826-833.

Daniels, M. J., Barber, C. E., Turner, P. C., Cleary, W. G., and Sawczyc, M. K. 1984. Isolation of mutants of Xanthomonas campestris pathovar campestris showing altered pathogenicity. J. Gen. Microbiol. 130:2447-2455.

Dean, P. 2011. Functional domains and motifs of bacterial type III effector proteins and their roles in infection. FEMS Microbiol. Rev. 35:1100-1125.

Deblaere, R., Bytebier, B., De Greve, H., Deboeck, F., Schell, J., Van Montagu, M., and Leemans, J. 1985. Efficient octopine Ti plasmid-derived vectors for Agrobacterium-mediated gene transfer to plants. Nucleic Acids Res. 13: 4777-4788.

Deng, W., Marshall, N. C., Rowland, J. L., McCoy, J. M., Worrall, L. J., Santos, A. S., Strynadka, N. C. J., and Finlay, B. B. 2017. Assembly, structure, function and regulation of type III secretion systems. Nat. Rev. Microbiol. 15:323-337.

Diepold, A., and Armitage, J. P. 2015. Type III secretion systems: The bacterial flagellum and the injectisome. Philos. Trans. R. Soc. Lond. B Biol. Sci. 370:0020.

Diepold, A., Kudryashev, M., Delalez, N. J., Berry, R. M., and Armitage, J. P. 2015. Composition, formation, and regulation of the cytosolic c-ring, a dynamic component of the type III secretion injectisome. PLoS Biol. 13: e1002039.

Engler, C., Kandzia, R., and Marillonnet, S. 2008. A one pot, one step, precision cloning method with high throughput capability. PLoS One 3:e3647.

Enninga, J., Mounier, J., Sansonetti, P., and Tran Van Nhieu, G. 2005. Secretion of type III effectors into host cells in real time. Nat. Methods 2: 959-965.

Escolar, L., Van Den Ackerveken, G., Pieplow, S., Rossier, O., and Bonas, U. 2001. Type III secretion and in planta recognition of the Xanthomonas avirulence proteins AvrBs1 and AvrBsT. Mol. Plant Pathol. 2: 287-296.

Figurski, D. H., and Helinski, D. R. 1979. Replication of an origincontaining derivative of plasmid RK2 dependent on a plasmid function provided in trans. Proc. Natl. Acad. Sci. U.S.A. 76:1648-1652.

Galán, J. E., Lara-Tejero, M., Marlovits, T. C., and Wagner, S. 2014. Bacterial type III secretion systems: Specialized nanomachines for protein delivery into target cells. Annu. Rev. Microbiol. 68:415-438. 
Greenberg, J. T., and Vinatzer, B. A. 2003. Identifying type III effectors of plant pathogens and analyzing their interaction with plant cells. Curr. Opin. Microbiol. 6:20-28.

Guttman, D. S., Vinatzer, B. A., Sarkar, S. F., Ranall, M. V., Kettler, G., and Greenberg, J. T. 2002. A functional screen for the type III (Hrp) secretome of the plant pathogen Pseudomonas syringae. Science 295: 1722-1726.

Hartmann, N., and Büttner, D. 2013. The inner membrane protein HrcV from Xanthomonas spp. is involved in substrate docking during type III secretion. Mol. Plant-Microbe Interact. 26:1176-1189.

Hartmann, N., Schulz, S., Lorenz, C., Fraas, S., Hause, G., and Büttner, D. 2012. Characterization of HrpB2 from Xanthomonas campestris pv. vesicatoria identifies protein regions that are essential for type III secretion pilus formation. Microbiology 158:1334-1349.

He, S. Y. 1998. Type III protein secretion systems in plant and animal pathogenic bacteria. Annu. Rev. Phytopathol. 36:363-392.

Hu, B., Lara-Tejero, M., Kong, Q., Galan, J.E., and Liu, J. 2017. In situ molecular architecture of the Salmonella type III secretion machine. Cell 168:1065-1074.e1010.

Hu, B., Morado, D. R., Margolin, W., Rohde, J. R., Arizmendi, O., Picking, W. L., Picking, W. D., and Liu, J. 2015. Visualization of the type III secretion sorting platform of Shigella flexneri. Proc. Natl. Acad. Sci. U.S.A. 112:1047-1052

Hueck, C. J. 1998. Type III protein secretion systems in bacterial pathogens of animals and plants. Microbiol. Mol. Biol. Rev. 62:379-433.

Kim, B. H., Kim, H. G., Kim, J. S., Jang, J. I., and Park, Y. K. 2007. Analysis of functional domains present in the N-terminus of the SipB protein. Microbiology 153:2998-3008.

Knoop, V., Staskawicz, B., and Bonas, U. 1991. Expression of the avirulence gene avrBs3 from Xanthomonas campestris pv. vesicatoria is not under the control of $h r p$ genes and is independent of plant factors. J. Bacteriol. 173:7142-7150.

Kousik, C. S., and Ritchie, D. F. 1998. Response of bell pepper cultivars to bacterial spot pathogen races that individually overcome major resistance genes. Plant Dis. 82:181-186.

Kovach, M. E., Elzer, P. H., Hill, D. S., Robertson, G. T., Farris, M. A., Roop, R. M., 2nd, and Peterson, K. M. 1995. Four new derivatives of the broad-host-range cloning vector $\mathrm{pBBR} 1 \mathrm{MCS}$, carrying different antibioticresistance cassettes. Gene 166:175-176.

Lonjon, F., Turner, M., Henry, C., Rengel, D., Lohou, D., van de Kerkhove, Q., Cazalé, A. C., Peeters, N., Genin, S., and Vailleau, F. 2016. Comparative secretome analysis of Ralstonia solanacearum type 3 secretion-associated mutants reveals a fine control of effector delivery, essential for bacterial pathogenicity. Mol. Cell. Proteomics 15:598-613.

Lorenz, C., and Büttner, D. 2009. Functional characterization of the type III secretion ATPase HrcN from the plant pathogen Xanthomonas campestris pv. vesicatoria. J. Bacteriol. 191:1414-1428.

Lorenz, C., and Büttner, D. 2011. Secretion of early and late substrates of the type III secretion system from Xanthomonas is controlled by $\mathrm{HpaC}$ and the C-terminal domain of HrcU. Mol. Microbiol. 79:447-467.

Lorenz, C., Hausner, J., and Büttner, D. 2012. HrcQ provides a docking site for early and late type III secretion substrates from Xanthomonas. PLoS One 7:e51063.

Lorenz, C., Kirchner, O., Egler, M., Stuttmann, J., Bonas, U., and Büttner, D. 2008a. HpaA from Xanthomonas is a regulator of type III secretion. Mol. Microbiol. 69:344-360.

Lorenz, C., Schulz, S., Wolsch, T., Rossier, O., Bonas, U., and Büttner, D. 2008b. HpaC controls substrate specificity of the Xanthomonas type III secretion system. PLoS Pathog. 4:e1000094.

Löwer, M., and Schneider, G. 2009. Prediction of type III secretion signals in genomes of gram-negative bacteria. PLoS One 4:e5917.

Majander, K., Anton, L., Antikainen, J., Lång, H., Brummer, M., Korhonen, T. K., and Westerlund-Wikström, B. 2005. Extracellular secretion of polypeptides using a modified Escherichia coli flagellar secretion apparatus. Nat. Biotechnol. 23:475-481.

Mattei, P. J., Faudry, E., Job, V., Izoré, T., Attree, I., and Dessen, A. 2011. Membrane targeting and pore formation by the type III secretion system translocon. FEBS J. 278:414-426.

McDermott, J. E., Corrigan, A., Peterson, E., Oehmen, C., Niemann, G., Cambronne, E. D., Sharp, D., Adkins, J. N., Samudrala, R., and Heffron, F. 2011. Computational prediction of type III and IV secreted effectors in gram-negative bacteria. Infect. Immun. 79:23-32.

Ménard, R., Sansonetti, P. J., and Parsot, C. 1993. Nonpolar mutagenesis of the ipa genes defines IpaB, IpaC, and IpaD as effectors of Shigella flexneri entry into epithelial cells. J. Bacteriol. 175:5899-5906.

Mills, E., Baruch, K., Charpentier, X., Kobi, S., and Rosenshine, I. 2008. Real-time analysis of effector translocation by the type III secretion system of enteropathogenic Escherichia coli. Cell Host Microbe 3:104-113.
Minsavage, G. V., Dahlbeck, D., Whalen, M. C., Kearny, B., Bonas, U., Staskawicz, B. J., and Stall, R. E. 1990. Gene-for-gene relationships specifying disease resistance in Xanthomonas campestris pv. vesicatoria pepper interactions. Mol. Plant-Microbe Interact. 3:41-47.

Morbitzer, R., Elsaesser, J., Hausner, J., and Lahaye, T. 2011. Assembly of custom TALE-type DNA binding domains by modular cloning. Nucleic Acids Res. 39:5790-5799.

Morello, J. E., and Collmer, A. 2009. Pseudomonas syringae HrpP Is a type III secretion substrate specificity switch domain protein that is translocated into plant cells but functions atypically for a substrateswitching protein. J. Bacteriol. 191:3120-3131.

Mudgett, M. B., Chesnokova, O., Dahlbeck, D., Clark, E. T., Rossier, O., Bonas, U., and Staskawicz, B. J. 2000. Molecular signals required for type III secretion and translocation of the Xanthomonas campestris AvrBs2 protein to pepper plants. Proc. Natl. Acad. Sci. U.S.A. 97:13324-13329.

Mueller, C. A., Broz, P., and Cornelis, G. R. 2008. The type III secretion system tip complex and translocon. Mol. Microbiol. 68:1085-1095.

Niemann, G. S., Brown, R. N., Mushamiri, I. T., Nguyen, N. T., Taiwo, R., Stufkens, A., Smith, R. D., Adkins, J. N., McDermott, J. E., and Heffron, F. 2013. RNA type III secretion signals that require Hfq. J. Bacteriol. 195: 2119-2125.

Noël, L., Thieme, F., Gäbler, J., Büttner, D., and Bonas, U. 2003. XopC and XopJ, two novel type III effector proteins from Xanthomonas campestris pv. vesicatoria. J. Bacteriol. 185:7092-7102.

Noël, L., Thieme, F., Nennstiel, D., and Bonas, U. 2002. Two novel type IIIsecreted proteins of Xanthomonas campestris pv. vesicatoria are encoded within the hrp pathogenicity island. J. Bacteriol. 184:1340-1348.

Oh, C. S., Carpenter, S. C., Hayes, M. L., and Beer, S. V. 2010. Secretion and translocation signals and DspB/F-binding domains in the type III effector DspA/E of Erwinia amylovora. Microbiology 156:1211-1220.

Petnicki-Ocwieja, T., Schneider, D. J., Tam, V. C., Chancey, S. T., Shan, L. Jamir, Y., Schechter, L. M., Janes, M. D., Buell, C. R., Tang, X., Collmer, A., and Alfano, J. R. 2002. Genomewide identification of proteins secreted by the Hrp type III protein secretion system of Pseudomonas syringae pv. tomato DC3000. Proc. Natl. Acad. Sci. U.S.A. 99:7652-7657.

Raymond, B., Young, J. C., Pallett, M., Endres, R. G., Clements, A., and Frankel, G. 2013. Subversion of trafficking, apoptosis, and innate immunity by type III secretion system effectors. Trends Microbiol. 21:430-441.

Rodgers, L., Gamez, A., Riek, R., and Ghosh, P. 2008. The type III secretion chaperone SycE promotes a localized disorder-to-order transition in the natively unfolded effector YopE. J. Biol. Chem. 283: 20857-20863.

Römer, P., Hahn, S., Jordan, T., Strauss, T., Bonas, U., and Lahaye, T. 2007. Plant pathogen recognition mediated by promoter activation of the pepper Bs3 resistance gene. Science 318:645-648.

Rossier, O., Van den Ackerveken, G., and Bonas, U. 2000. HrpB2 and HrpF from Xanthomonas are type III-secreted proteins and essential for pathogenicity and recognition by the host plant. Mol. Microbiol. 38: 828-838.

Rossier, O., Wengelnik, K., Hahn, K., and Bonas, U. 1999. The Xanthomonas Hrp type III system secretes proteins from plant and mammalian bacterial pathogens. Proc. Natl. Acad. Sci. U.S.A. 96:9368-9373.

Rüssmann, H., Kubori, T., Sauer, J., and Galán, J. E. 2002. Molecular and functional analysis of the type III secretion signal of the Salmonella enterica InvJ protein. Mol. Microbiol. 46:769-779.

Samudrala, R., Heffron, F., and McDermott, J. E. 2009. Accurate prediction of secreted substrates and identification of a conserved putative secretion signal for type III secretion systems. PLoS Pathog. 5:e1000375.

Schechter, L. M., Roberts, K. A., Jamir, Y., Alfano, J. R., and Collmer, A 2004. Pseudomonas syringae type III secretion system targeting signals and novel effectors studied with a Cya translocation reporter J. Bacteriol. 186:543-555.

Schechter, L. M., Valenta, J. C., Schneider, D. J., Collmer, A., and Sakk, E. 2012. Functional and computational analysis of amino acid patterns predictive of type III secretion system substrates in Pseudomonas syringae. PLoS One 7:e36038.

Schechter, L. M., Vencato, M., Jordan, K. L., Schneider, S. E., Schneider, D. J., and Collmer, A. 2006. Multiple approaches to a complete inventory of Pseudomonas syringae pv. tomato DC3000 type III secretion system effector proteins. Mol. Plant-Microbe Interact. 19:1180-1192.

Scheibner, F., Schulz, S., Hausner, J., Marillonnet, S., and Büttner, D. 2016. Type III-dependent translocation of HrpB2 by a non-pathogenic hpaABC mutant of the plant-pathogenic bacterium Xanthomonas campestris pv. vesicatoria. Appl. Environ. Microbiol. 82:3331-3347.

Schesser, K., Frithz-Lindsten, E., and Wolf-Watz, H. 1996. Delineation and mutational analysis of the Yersinia pseudotuberculosis YopE domains which mediate translocation across bacterial and eukaryotic cellular membranes. J. Bacteriol. 178:7227-7233. 
Schlumberger, M. C., Müller, A. J., Ehrbar, K., Winnen, B., Duss, I., Stecher, B., and Hardt, W. D. 2005. Real-time imaging of type III secretion: Salmonella SipA injection into host cells. Proc. Natl. Acad. Sci. U.S.A. 102:12548-12553.

Schulze, S., Kay, S., Büttner, D., Egler, M., Eschen-Lippold, L., Hause, G., Krüger, A., Lee, J., Müller, O., Scheel, D., Szczesny, R., Thieme, F., and Bonas, U. 2012. Analysis of new type III effectors from Xanthomonas uncovers XopB and XopS as suppressors of plant immunity. New Phytol. 195:894-911.

Singer, H. M., Erhardt, M., and Hughes, K. T. 2014. Comparative analysis of the secretion capability of early and late flagellar type III secretion substrates. Mol. Microbiol. 93:505-520.

Sorg, I., Wagner, S., Amstutz, M., Müller, S. A., Broz, P., Lussi, Y., Engel, A., and Cornelis, G. R. 2007. YscU recognizes translocators as export substrates of the Yersinia injectisome. EMBO J. 26:3015-3024.

Sorg, J. A., Blaylock, B., and Schneewind, O. 2006. Secretion signal recognition by YscN, the Yersinia type III secretion ATPase. Proc. Natl. Acad. Sci. U.S.A. 103:16490-16495.

Sory, M. P., Boland, A., Lambermont, I., and Cornelis, G. R. 1995. Identification of the YopE and YopH domains required for secretion and internalization into the cytosol of macrophages, using the cyaA gene fusion approach. Proc. Natl. Acad. Sci. U.S.A. 92:11998-12002.

Szczesny, R., Jordan, M., Schramm, C., Schulz, S., Cogez, V., Bonas, U., and Büttner, D. 2010. Functional characterization of the Xcs and Xps type II secretion systems from the plant pathogenic bacterium Xanthomonas campestris pv vesicatoria. New Phytol. 187:983-1002.

Szurek, B., Rossier, O., Hause, G., and Bonas, U. 2002. Type III-dependent translocation of the Xanthomonas AvrBs3 protein into the plant cell. Mol. Microbiol. 46:13-23.

Thieme, F., Szczesny, R., Urban, A., Kirchner, O., Hause, G., and Bonas, U. 2007. New type III effectors from Xanthomonas campestris pv. vesicatoria trigger plant reactions dependent on a conserved $\mathrm{N}$ myristoylation motif. Mol. Plant-Microbe Interact. 20:1250-1261.

Thomas, N. A., Deng, W., Puente, J. L., Frey, E. A., Yip, C. K., Strynadka, N. C., and Finlay, B. B. 2005. CesT is a multi-effector chaperone and recruitment factor required for the efficient type III secretion of both LEE- and non-LEE-encoded effectors of enteropathogenic Escherichia coli. Mol. Microbiol. 57:1762-1779.

Thomas, N. A., Ma, I., Prasad, M. E., and Rafuse, C. 2012. Expanded roles for multicargo and class $1 \mathrm{~B}$ effector chaperones in type III secretion. J. Bacteriol. 194:3767-3773.

Tomalka, A. G., Stopford, C. M., Lee, P. C., and Rietsch, A. 2012. A translocator-specific export signal establishes the translocator-effector secretion hierarchy that is important for type III secretion system function. Mol. Microbiol. 86:1464-1481.

VanEngelenburg, S. B., and Palmer, A. E. 2008. Quantification of real-time Salmonella effector type III secretion kinetics reveals differential secretion rates for SopE2 and SptP. Chem. Biol. 15:619-628.

Wang, Y., Sun, M., Bao, H., Zhang, Q., and Guo, D. 2013. Effective identification of bacterial type III secretion signals using joint element features. PLoS One 8:e59754.

Weber, E., Ojanen-Reuhs, T., Huguet, E., Hause, G., Romantschuk, M., Korhonen, T. K., Bonas, U., and Koebnik, R. 2005. The type IIIdependent Hrp pilus is required for productive interaction of Xanthomonas campestris pv. vesicatoria with pepper host plants. J. Bacteriol. 187:2458-2468.

Wengelnik, K., and Bonas, U. 1996. HrpXv, an AraC-type regulator, activates expression of five of the six loci in the hrp cluster of Xanthomonas campestris pv. vesicatoria. J. Bacteriol. 178:3462-3469.

Wengelnik, K., Rossier, O., and Bonas, U. 1999. Mutations in the regulatory gene hrpG of Xanthomonas campestris pv. vesicatoria result in constitutive expression of all hrp genes. J. Bacteriol. 181:6828-6831.

Wengelnik, K., Van den Ackerveken, G., and Bonas, U. 1996. HrpG, a key hrp regulatory protein of Xanthomonas campestris pv. vesicatoria is homologous to two-component response regulators. Mol. Plant-Microbe Interact. 9:704-712.

Winnen, B., Schlumberger, M. C., Sturm, A., Schüpbach, K., Siebenmann, S., Jenny, P., and Hardt, W. D. 2008. Hierarchical effector protein transport by the Salmonella Typhimurium SPI-1 type III secretion system. PLoS One 3:e2178. 